\title{
A Oligarquia Desvendada: Organização e Estrutura dos Partidos Políticos Brasileiros
}

\author{
Andre Rehbein Sathler Guimarães ${ }^{1}$ \\ Malena Rehbein Rodrigues ${ }^{2}$ \\ Ricardo de João Braga ${ }^{3}$ \\ ${ }^{1}$ Docente no Mestrado Profissional em Poder Legislativo do Cefor / Câmara dos Deputados. Brasília, \\ DF. Brasil. \\ Email: andre.sathler@gmail.com, http:/ / orcid.org/0000-0003-1856-9839 \\ ${ }^{2}$ Docente no Mestrado Profissional em Poder Legislativo do Cefor / Câmara dos Deputados. Brasília, \\ DF. Brasil. \\ E-mail: malena.rodrigues@camara.leg.br, http:/ / orcid.org/0000-0002-3059-5098 \\ ${ }^{3}$ Docente no Mestrado Profissional em Poder Legislativo do Cefor / Câmara dos Deputados. Brasília, \\ DF. Brasil. \\ E-mail: ricardo.braga@camara.leg.br, https://orcid.org/0000-0002-0007-9746
}

\section{INTRODUÇÃO}

\begin{abstract}
$\mathrm{O}$ s partidos políticos sempre foram considerados, estruturalmente, espécies institucionais de mediação com a sociedade (Weber, 1999), ainda que a literatura sobre partidos aponte uma quase anulação dessa função a partir da dependência estatal que os partidos desenvolveram na atualidade (Amaral, 2013; Mainwaring, 2001). Mesmo que essa função tenha sofrido concorrência com a participação crescente por outras vias que não só institucionais (Manin, 2013), como os meios de comunicação em rede, é inegável o papel importante dos partidos políticos na contemporaneidade para, pelo menos: recrutar candidatos e simplificar as escolhas dos cidadãos; organizar a disputa e o financiamento eleitorais; e dividir poder nas instâncias políticas em que participam (formando maiorias e minorias) (Dalton e Wattemberg, 2000). Desta forma, como argumentam Katz e Mair (1995), ao invés de focar em um possível declínio dos partidos, talvez seja melhor entender o processo de mudança em seu funcionamento. Trata-se de adaptação, mais do que propriamente de uma crise de partidos.
\end{abstract}

DADOS, Rio de Janeiro, vol.62(2):e20160046, 2019. 
Na Europa, a evolução dos partidos relacionou-se muito mais a critérios ideológicos que no Brasil, embora tais vínculos estejam hoje enfraquecidos em relação ao que foram no passado (Panebianco, 2005). Quando se consideram as principais referências teóricas sobre partidos, vê-se uma evolução analítica que faz frente à mudança estrutural e funcional enfrentadas por esses, desde a histórica tipologia de partidos de quadros versus partidos de massas, de Duverger (1980 [1951]). Kirchheimer (1966), advogou o conceito de partido catch all, já mais voltado para a função eleitoral, um conceito de certa forma evoluído a partir do de partido cartel que, além de ter viés eleitoral, depende grandemente do Estado, a quem, por isso, concederia parte do seu próprio papel de mediador (Katz e Mair, 1995); e de partido profissional-eleitoral, de Panebianco (2005). Entretanto, independente das tipologias de funções utilizadas ao longo da trajetória de estudos, as críticas atuais da literatura apontam para o fato de que todas elas podem não conseguir explicar a multiplicidade de características dos partidos e que, por isso, seria interessante, antes de tudo, observar o comportamento das agremiações (Amaral, 2013:19).

A forma como os partidos atuam e se comportam depende de fatores anteriores, como a organização interna de cada um deles, objeto ainda de poucos estudos a respeito (Amaral, 2013:25). Referências consolidadas na literatura sobre partidos políticos, como Duverger (1980), Sartori (1982), Michels (1949), Mainwaring (2001) apontam para a importância dessa organização como um dos elementos definidores da qualidade do sistema político e partidário. Essas referências, entretanto, não se aprofundam no tema organização e estrutura interna dos partidos políticos, cobrindo uma vasta série de outras questões (competitividade sistêmica, posicionamento ideológico, influência do sistema partidário sobre democracia, quantidade de partidos e qualidade do sistema político etc.).

Já Hazan e Rahat (2010) apontam para a necessidade de estudar a democracia intrapartidária como dimensão relevante à teoria democrática, mais focada, segundo esses autores, na competição interpartidária. Eles partem da premissa de que a seleção de candidatos, realizada internamente aos partidos, afeta a natureza da democracia. Seus estudos concluem que o fato de a seleção dos candidatos no âmbito intrapartidário não ser democrática não afeta o nível e qualidade da democracia em geral (Hazan e Rahat, 2010; Rahat, Hazan e Katz, 2008). O presente estudo complementa a perspectiva desses 
autores, demonstrando as formas efetivas de gestão não democrática em âmbito intrapartidário, além de trazer um conjunto de dados que permitem tanto a identificação de clusters de práticas prevalentes, bem como uma comparação sistemática entre partidos.

Assim, o presente artigo foca na organização e estrutura interna dos partidos políticos brasileiros, a partir de uma abordagem institucionalista tradicional, uma vez que se busca compreender como um conjunto específico de regras [estatutos partidários] pode afetar a comunidade de atores [partidos, lideranças partidárias, filiados] e as relações entre esses grupos. Conforme Hall e Taylor, é uma tendência dessa abordagem "associar as instituições às organizações e às regras ou convenções editadas pelas organizações formais" (Hall e Taylor, 2003:194). Assume-se que as regras importam, que elas influenciam o comportamento dos atores, suas possibilidades e escolhas, sem deixar de levar em consideração que os interesses, preferências e objetivos também são determinantes do resultado final.

As regras influenciam a determinação das estratégias dos atores dentro do sistema, e seu estudo contribui para o entendimento dos diferentes resultados possíveis para o quadro institucional mais amplo. Evidentemente, não se trata de postular a completa validade das regras, nem tampouco sua suficiência causal ou explicativa. Como apresentado por Sartori:

os estatutos partidários contêm, grosso modo, três elementos principais: uma série de proibições, a estrutura organizacional e as disposições eleitorais. As p0roibições podem ser tacitamente ignoradas, à base da hipocrisia recíproca, e sua efetividade é bastante incerta. Sartori (1982:119).

Não se pretende ignorar o alerta de Sartori quanto à efetividade das regras, mas sim valorizar sua chamada de atenção para o fato de que nos estatutos encontram-se os elementos básicos da estrutura organizacional dos partidos políticos. Michels (1949) aponta que o melhor local para identificar tendências oligarquizantes seria a estrutura íntima dos partidos, a qual se desnuda em seus estatutos. Se é fato que as regras podem ser ignoradas, também é certo que as regras estatutárias - dada sua posição como regras instituintes, que conferem ipso facto o "nascimento" da pessoa jurídica do partido, no caso brasileiro - podem em última instância ser invocadas e adjudicadas. 
Pretende-se com o estudo, a partir de uma perspectiva normogenéti$\mathrm{ca}$, identificar como se organizam e estruturam internamente os partidos políticos brasileiros. A partir dessa identificação, busca-se verificar os elementos organizativos ou estruturais que configurem tipos de comportamento partidários, como características oligárquicas nos partidos políticos brasileiros, em confronto com o anunciado pelas referências clássicas já mencionadas (Duverger, 1980; Sartori, 1982; Michels, 1949). Esforço similar foi feito por Ribeiro (2013), o qual, entretanto, foca em duas dimensões: grau de inclusividade da estrutura decisória e grau de centralização orgânica. O estudo de Ribeiro (2013) também escolhe como objeto apenas quatro partidos: PMDB, PSDB, PT e DEM. Dado o seu enfoque, bem como as questões que orientaram sua pesquisa, o trabalho de Ribeiro (2013) diferencia-se do presente artigo, embora ambos se aproximem, inclusive em termos de alguns de seus achados, o que é interessante do ponto de vista de sua validação. Assim como Ribeiro, o presente estudo dialoga com a literatura existente sobre partidos políticos, sem adotar a priori um referencial específico como paradigma.

O corpus da pesquisa constitui-se, portanto, do conjunto dos estatutos dos partidos políticos brasileiros em julho de 2015 (32 partidos ${ }^{1}$ ). No caso dos partidos políticos brasileiros, o estatuto é componente obrigatório do seu registro junto ao Tribunal Superior Eleitoral (Lei 9.096/95) e apresenta características de discurso perlocucionário, pois faz existir. Trata-se do gérmen principal do ordenamento jurídico dos partidos, devendo ser considerado como fonte primária em sua consideração formal, bem como fonte material ou de conteúdo, assinalando tanto o ubi jus quanto o unde jus, ou seja, de onde o Direito se localiza e de onde o Direito procede. Interna corporis, o estatuto é a norma hierarquicamente superior e expressa o consenso sobre os valores básicos da entidade. A escolha dos estatutos como objeto da pesquisa justifica-se também pela compreensão de que os partidos políticos devem ser entendidos em seus próprios termos, em outras palavras, os partidos são o que dizem ser. Suas práticas e sobretudo as práticas discursivas são sua autodefinição. 
Quadro 1

Corpus da pesquisa. Partidos Políticos Brasileiros. Julho de 2015.

\begin{tabular}{lc}
\hline Partido & Sigla \\
\hline Democratas & DEM \\
Partido Comunista Brasileiro & PCB \\
Partido Comunista do Brasil & PCdoB \\
Partido da Causa Operária & PCO \\
Partido da Mobilização Nacional & PMN \\
Partido da República & PR \\
Partido da Social Democracia Brasileira & PSDB \\
Partido Democrático Trabalhista & PDT \\
Partido do Movimento Democrático Brasileiro & PMDB \\
Partido dos Trabalhadores & PT \\
Partido Ecológico Nacional & PEN \\
Partido Humanista da Solidariedade & PHS \\
Partido Pátria Livre & PPL \\
Partido Popular Socialista & PPS \\
Partido Progressista & PP \\
Partido Renovador Trabalhista Brasileiro & PRTB \\
Partido Republicano Brasileiro & PRB \\
Partido Republicano da Ordem Social & PROS \\
Partido Republicano Progressista & PRP \\
Partido Social Cristão & PSC \\
Partido Social Democrata Cristão & PSDC \\
Partido Social Democrático & PSD \\
Partido Social Liberal & PSL \\
Partido Socialismo e Liberdade & PSOL \\
Partido Socialista Brasileiro & PSB \\
Partido Socialista dos Trabalhadores Unificado & PSTU \\
Partido Trabalhista Brasileiro & PTB \\
Partido Trabalhista Cristão & PTC \\
Partido Trabalhista do Brasil & PTdoB \\
Partido Trabalhista Nacional & PTN \\
Partido Verde & PV \\
Solidariedade & SD \\
\hline Fole Elote
\end{tabular}

Fonte: Elaborado pelos autores, a partir dos dados do Tribunal Superior Eleitoral (TSE) (ver Nota 1). 
É uma pesquisa documental, de cunho exploratório. Em alguns momentos, são construídos índices operacionais que permitem uma avaliação em relação às dimensões "filiação" e "desfiliação". Valores mais elevados nos índices construídos representam, respectivamente, mais dificuldades em se filiar e mais dificuldade em se manter filiado. Trata-se de uma proposta compatível com o caráter exploratório da pesquisa, reconhecido o fato de que podem existir outras formas de tratamento e estudo dos dados.

O artigo organiza-se basicamente em quatro partes, consideradas estruturais dentro dos estatutos: organização e controle dos filiados; organização e estrutura interna; dirigentes partidários; e alterações estatutárias. A análise do ponto de vista de categorias estruturais será feita segundo as notações usadas por Duverger (1980).

\section{ORGANIZAÇÃO E CONTROLE DOS FILIADOS}

Começando pela adesão, requisito fundamental para a formação dos partidos, segundo identificado por Duverger (1980), há a adesão aberta, em que basicamente só é preenchida a ficha de adesão ${ }^{2}$, e a adesão regulamentada. No caso brasileiro, todas as adesões são regulamentadas, uma vez que são previstas condições e procedimentos especiais nas normas estatutárias. Com a perspectiva de estabelecer o maior ou menor grau de dificuldade para se conseguir a filiação partidária, trabalhou-se com a construção de um índice somatório simples, relacionado a "quem pode se filiar", com uma gradação que vai de " 0 " a " 3 ", sendo " 3 " a gradação mais restritiva. Ao final, pontuações mais elevadas significam partidos mais restritivos em termos de aceitação de novos filiados. $\mathrm{O}$ "quem se pode filiar" foi desmembrado conforme as características exigíveis dos postulantes à filiação encontradas no corpus: nacionalidade, idade, situação eleitoral, necessidade de abono, possibilidade de impugnação, restrições de caráter pessoal e existência de exigências adicionais.

No quesito "nacionalidade", identificaram-se as seguintes respostas: "não mencionado", "qualquer pessoa", "brasileiro"; "legalmente equiparado a brasileiro" e "cidadão". Atribuiu-se "0" para "não mencionado" e "qualquer pessoa", "1" para "brasileiro" ou "legalmente equiparado a brasileiro" e " 2 " para cidadão. Compreendeu-se que o conceito jurídico de "cidadão", no plano constitucional, é mais estreito do que o de brasileiro. Ser cidadão implica exercício de direitos e 
deveres, inclusive os eleitorais, o que não se estende a todos os brasileiros (cf. Tesseroli Filho, 2015).

Quanto à idade, atribuiu-se "0" para "não mencionado", "1" para "16 anos ou menos"; " 2 " para "16 anos ou mais" e " 3 " para "18 anos". Os casos de "16 anos ou menos" representam iniciativas de filiados mirins, que exercem todas as atividades no partido, exceto as eleitorais. Trata-se de proposta de incorporação dos púberes e sua doutrinação política. Nos casos em que, quanto à capacidade eleitoral das pessoas, foi afirmado que deveriam estar no pleno gozo de seus direitos políticos e não foi mencionada a idade, presumiu-se a idade de 16 anos. Há que se ressaltar que a lei dos partidos políticos (Lei no 9.096/95), em seu art. 16, ressalta que "só pode filiar-se a partido o eleitor que estiver no pleno gozo de seus direitos políticos". Porém, infralegalmente, o TSE reconhece que a inelegibilidade não impede a filiação partidária (Resolução TSE $\mathrm{n}^{\circ}$ 23.117/2009). Alguns autores (ie. Tesseroli Filho, 2015) compreendem que o pleno gozo dos direitos políticos só acontece aos 18 anos, porque, apesar de poder ser eleitor aos 16, há alguns direitos políticos inacessíveis aos jovens dessa faixa etária, como o de serem eleitos - a menor idade para ser eleito vereador é 18 anos (CF, art. 14, Inc. VI, alínea d).

Sobre capacidade eleitoral, distinguiu-se com "0" a resposta "não mencionado"; " 1 " à resposta os "eleitores" e " 2 " a os em "pleno gozo dos direitos políticos". Conforme apontado anteriormente, o "pleno gozo dos direitos políticos" deveria acompanhar-se de idade mínima de 16 anos e de exigência da condição de "cidadão" no campo nacionalidade. Em alguns casos, há a menção explícita da idade mínima, acompanhada da expressão "pleno gozo" - PMDB; PSDB; PRP; PSOL; SD; o que se constitui em incoerência formal.

No tocante à necessidade de "abono" do candidato à filiação (o "apadrinhamento obrigatório", de Duverger, 1980), gradou-se em "0" o "não mencionado", "1" o "abono simples" e "2" o "abono qualificado". O abono simples é aquele feito por qualquer filiado, o abono qualificado ocorre quando requer uma condição diferenciada do filiado abonante, como, por exemplo, ser membro de executiva ou de diretório.

Com relação à possibilidade de impugnação, trabalhou-se apenas com a dimensão "prazo". Para os casos "não mencionado" foi atribuído " 0 ". Para prazos de até 3 dias, foi atribuído " 1 ". Para prazos de 
4 a 7 dias foi atribuído "2". Para prazos maiores ou para aqueles em que foi mencionada a possibilidade de impugnação, mas sem data, foi atribuído " 3 ". Compreende-se que, quanto maior o prazo para a impugnação, maior é a possibilidade de que venha a ser impugnada, ou seja, mais restritiva a condição.

Foram identificadas outras condições restritivas. Nesses casos, atribuiu-se " 0 " quando a condição inexiste e " 3 " para a presença da condição. Há restrições para filiações em bloco, explicitamente formuladas para evitar a tomada de assalto do partido por grupos estranhos - por exemplo:

o pedido de filiação será indeferido nos casos de filiações em bloco que objetivem o predomínio de pessoas ou grupos estranhos ou sem afinidade com o Partido (PMDB, art. 5º, $§ 3^{\circ}$, alínea e).

Duas outras restrições que também se vinculam a uma preocupação com a manutenção do controle partidário são relacionadas à filiação de "políticos" (termos verificados: dirigentes partidários; ex-dirigentes; dirigentes de outros partidos; secretários de governo; ex-secretários; parlamentares; ex-parlamentares; prefeitos; ex-prefeitos; governadores; ex-governadores; ministros; ex-ministros; presidentes; ex-presidentes da República; detentores de cargos eletivos) e de "personalidades" (termos verificados: grandes empresários; personalidades de projeção nacional ou regional; personalidades da sociedade civil; notória expressão pública; líderes de reconhecida expressão). Ressalte-se que, nos casos em que se constatou a existência dessa restrição, há um aspecto condicionante - usualmente a necessidade de aprovação da filiação pela Executiva Nacional do partido - e não de bloqueio ${ }^{3}$.

Há uma restrição a pessoas que tenham vínculo partidário anterior (DEM, PTC, PP, PSD). Trata-se de uma restrição redundante, uma vez que a lei dos partidos políticos veda a dupla filiação ${ }^{4}$. Apesar do caráter redundante, como nem todos os partidos apresentam a restrição explicitamente em seus estatutos, foi mantida a pontuação para esta restrição.

Existem restrições relacionadas a membros que tenham se desligado ou sido desligados do próprio partido anteriormente: "que tenha saído voluntariamente antes ou que tenha tido filiação cancelada" (PSDB); "ex-integrantes que tenham sofrido processo condenatório 
pelo Tribunal de Ética e Disciplina Partidária" (PMN); "expulsos do partido por deliberação legítima de qualquer órgão de direção partidária; por decisão em última instância foram impedidos de se filiar" (PTN; PROS). Apenas um partido apresentou uma restrição de cunho comportamental, o PV:

indivíduos comprovadamente responsáveis por violação dos direitos humanos, agressão ao meio ambiente ou corrupção, bem como atitudes ou manifestações ofensivas ou discriminatórias à origem étnica, à orientação sexual, de gênero e à crença.

No campo "exigências adicionais" foram identificados: "obrigatoriedade de comparecimento à reunião de apresentação da história e concepção do Partido", em um determinado período de tempo, para confirmação da filiação (PT); necessidade de pagamento de taxa de filiação (PMN; PRP). Para cada exigência adicional prevista foi atribuído "3".

Os resultados são consolidados no Quadro 2 e discriminados no Quadro 3. Os partidos foram divididos em três intervalos, aos quais os autores denominaram de "receptivos", "seletivos", "aceptivos". Os "receptivos" (10 partidos) são aqueles que se aproximam do conceito de Duverger (1980) de adesão aberta, sendo praticamente a única condição para ingresso o preenchimento da ficha de adesão. Encontram-se nesse perfil partidos como PCO, PSTU e PROS. Apesar dos dois primeiros serem partidos de esquerda, o fato de terem tido sua origem já no período democrático [PCO - 30/9/1997; PSTU - 19/12/1995';] pode explicar a despreocupação desses com questões de perseguição política. PR (resultado da fusão do PL e PRONA, em 2006), PROS (2013) e SD (2013) também estão entre os receptivos provavelmente porque são partidos bastante recentes e em busca de legitimação.

Partidos receptivos são partidos pragmáticos em termos de filiação - quanto mais filiados, melhor. Os "seletivos" são partidos que adotam algumas restrições e condicionantes à filiação, o que permite um certo grau de controle sobre os candidatos a membro. É o grupo majoritário, com 19 partidos. A preocupação predominante - presente em oito desses casos - é com a adesão de políticos, que precisa ser referendada por órgãos superiores dos partidos, como a Executiva Nacional. 
Os "aceptivos" são partidos que adotam restrições fortes à filiação. São eles o PCdoB, o PSDB e o PT. No caso do PCdoB, assume-se a explicação de Duverger:

a adesão regulamentada, com o apadrinhamento e decisão do partido, constitui o processo habitual nos estatutos dos partidos socialistas e comunistas; as precauções adotadas se explicam pelas dificuldades experimentadas por esses partidos na sua origem e notadamente os esforços da política para neles introduzir "secretas". (1980:108)

O prazo previsto para impugnações é de trinta dias, o maior registrado entre os partidos, bem como a idade mínima, apontada como 18 anos, apesar de existir uma excepcionalidade para admissão de maiores de 16 anos. Que o partido se preocupa com a sua composição revela-se ainda por um artigo peculiar e exclusivo de seu estatuto:

art. $4^{\circ}$. Os filiados e filiadas são um patrimônio político do Partido, que empreende esforços permanentes para elevar sua consciência política, sua participação na vida partidária e seu compromisso militante (PCdoB).

O PCdoB também é o único partido a ressalvar, explicitamente, precauções hierárquicas em casos de expulsão ${ }^{6}$.

Já o PT e o PSDB são os partidos que estiveram no Poder Executivo Federal nos últimos 21 anos. $\mathrm{O}$ acesso ao partido, nesses casos, representa acesso a recursos significativos, inclusive capacidade de nomeação a $\operatorname{cargos}^{7}$, uma possível explicação para o maior controle ao acesso $^{8}$.

Quadro 2

Partidos políticos. Requisitos para filiação. Consolidação.

\begin{tabular}{|c|c|c|c|c|}
\hline & $\begin{array}{c}\text { Receptivos } \\
0 \vdash 7\end{array}$ & & $\begin{array}{c}\text { Seletivos } \\
8 \vdash 15\end{array}$ & $\begin{array}{c}\text { Aceptivos } \\
16\end{array}$ \\
\hline $\begin{array}{c}\text { PR } \\
\text { PSTU }\end{array}$ & $\begin{array}{cc}\text { PSDC } & \text { PCD } \\
\text { PCB } & \text { PTB } \\
\text { PTdoB } & \text { SD }\end{array}$ & $\begin{array}{l}\text { PTC } \\
\text { PROS }\end{array}$ & $\begin{array}{cccc}\text { PSB } & \text { PSL } & \text { PRB } & \text { PSOL } \\
\text { PEN } & \text { DEM } & \text { PSC } & \text { PP } \\
\text { PRTB } & \text { PSD } & \text { PRP } & \text { PHS } \\
\text { PMDB } & \text { PTN } & \text { PPS } & \text { PV } \\
\text { PDT } & \text { PPL } & \text { PMN }\end{array}$ & $\begin{array}{l}\text { PCdoB } \\
\text { PT } \\
\text { PSDB }\end{array}$ \\
\hline
\end{tabular}

Fonte: Elaborado pelos autores, com base nos resultados do índice construído para a dimensão filiação. 
Quadro 3

Partidos Políticos. Requisitos de Filiação.

\begin{tabular}{|c|c|c|c|c|c|c|c|c|c|c|c|}
\hline \multirow[b]{2}{*}{ Sigla } & \multicolumn{3}{|c|}{ Quem } & \multirow[b]{2}{*}{ Abono } & \multirow[b]{2}{*}{ Impg } & \multicolumn{5}{|c|}{ Restriç̧ões } & \multirow{2}{*}{$\begin{array}{l}\text { Exigências } \\
\text { adicionais }\end{array}$} \\
\hline & $\mathrm{Nac}$ & Idade & Eleitor & & & Bloco & Políticos & Persona & $\begin{array}{l}\text { Vínculo } \\
\text { anterior }\end{array}$ & Outras & \\
\hline PMDB & $\mathrm{C}$ & 16 & PG & AS & 5 & Sim & Não & Não & Não & Não & \\
\hline РТВ & B & $16^{-b}$ & E & AS & 3 & Não & Não & Não & Não & Não & \\
\hline PDT & $\mathrm{B} / \mathrm{R}$ & 16 & NM & AS & 3 & Sim & Sim & Sim & Não & Não & \\
\hline PT & $\mathrm{L}$ & 16 & NM & NM & 7 & Sim & Sim & Sim & Não & Não & g \\
\hline DEM & NM & $\underline{16}^{\mathrm{a}}$ & PG & AS & 3 & Não & Não & Não & Sim & Não & \\
\hline PCdoB & $\mathrm{C}$ & $18-$ & PG & AS & 30 & Não & Sim & Sim & Não & Não & \\
\hline PSB & L & $\underline{16}$ & PG & AS & $\mathrm{NM}$ & Não & Sim & Não & Não & Não & \\
\hline PSDB & B & $16-$ & PG & AS & 5 & Sim & Sim & Sim & Não & Sim. ${ }^{c}$ & \\
\hline PTC & NM & $\mathrm{NM}$ & NM & NM & 3 & Não & Não & Não & Sim & Não & \\
\hline PSC & NM & $\underline{16}$ & PG & AS & 3 & Sim & Não & Não & Não & Não & \\
\hline PMN & $\mathrm{B} / \mathrm{LE}$ & $\underline{16}$ & PG & $\mathrm{NM}$ & 5 & Não & Não & Não & Não & Sim. ${ }^{d}$ & $\mathrm{~h}$ \\
\hline PRP & L & 16 & PG & $\mathrm{NM}$ & $\mathrm{NM}$ & Não & Sim & Não & Não & Não & $\mathrm{h}$ \\
\hline PPS & C & $\underline{16}$ & PG & AS & $\mathrm{NM}$ & Não & Sim & Sim & Não & Não & \\
\hline PV & B & $\underline{16}$ & PG & $\mathrm{AQ}$ & $\mathrm{NM}$ & Sim & Não & Não & Não & Sim. ${ }^{\text {e }}$ & \\
\hline PTdoB & B & $\underline{16}$ & E & $\mathrm{AQ}$ & 3 & Não & Não & Não & Não & Não & \\
\hline PP & C & $\mathrm{NM}$ & $\mathrm{NM}$ & NM & 3 & Não & Sim & Não & Sim & Não & \\
\hline PSTU & $\mathrm{L}$ & 16 & $\mathrm{NM}$ & $\mathrm{NM}$ & 3 & Não & Não & Não & Não & Não & \\
\hline PCB & $\mathrm{L}$ & NM & $\mathrm{NM}$ & AS & SDT & Não & Não & Não & Não & Não & \\
\hline PRTB & B & $\underline{16}$ & PG & $\mathrm{NM}$ & $2^{* *}$ & Não & Sim & Não & Não & Não & \\
\hline PHS & $\mathrm{C} / \mathrm{B}$ & $\underline{16}$ & E & NM & $\mathrm{NM}$ & Não & Sim & Sim & Não & Não & \\
\hline PSDC & $\mathrm{L}$ & $16-$ & E & NM & 3 & Não & Não & Não & Não & Não & \\
\hline PCO & $\mathrm{L}$ & $\mathrm{NM}$ & $\mathrm{NM}$ & $\mathrm{NM}$ & SDT & Não & Não & Não & Não & Não & \\
\hline PTN & $\mathrm{NM}$ & $\underline{16}$ & PG & $\mathrm{NM}$ & 3 & Não & Não & Não & Não & Sim. ${ }^{f}$ & \\
\hline PSL & C & $\underline{16}$ & PG & $\mathrm{NM}$ & 5 & Não & Não & Não & Não & Não & \\
\hline PRB & $\mathrm{NM}$ & $\underline{16}$ & PG & $\mathrm{NM}$ & 3 & Não & Sim & Não & Não & Não & \\
\hline PSOL & $\mathrm{L}$ & $16-$ & PG & $\mathrm{AQ}$ & 30 & Não & Sim & Não & Não & Não & \\
\hline PR & $\mathrm{L}$ & $16-$ & $\mathrm{NM}$ & $\mathrm{NM}$ & 3 & Não & Não & Não & Não & Não & \\
\hline PSD & L & $\underline{16}$ & PG & AS & 3 & Não & Não & Não & Sim & Não & \\
\hline PPL & B & 16 & $\mathrm{NM}$ & AS & 3 & Sim & Sim & Sim & Não & Não & \\
\hline PEN & $\mathrm{C} / \mathrm{B}$ & $\underline{16}$ & PG & $\mathrm{AQ}$ & $\mathrm{NM}$ & Não & Não & Não & Não & Não & \\
\hline PROS & B & $\underline{16}$ & PG & $\mathrm{NM}$ & $\mathrm{NM}$ & Não & Não & Não & Não & Sim. ${ }^{f}$ & \\
\hline $\mathrm{SD}$ & C & 16 & PG & $\mathrm{NM}$ & 3 & Não & Não & Não & Não & Não & \\
\hline
\end{tabular}

Fonte: Elaborado pelos autores, com base nas informações dos estatutos partidários.

Legenda: NAC= Nacionalidade; IMPUG = Impugnação; PERSONA = Personalidade; $\mathrm{C}=$ Cidadão; $\mathrm{B}=$ Brasileiro; $\mathrm{R}$ = Estrangeiro residente no Brasil; $\mathrm{LE}$ = Legalmente equiparado a brasileiro; $\mathrm{L}=$ Livre; $\mathrm{NM}=$ Não mencionado; $\mathrm{PG}=$ Pleno gozo dos direitos políticos; $\mathrm{E}=$ Eleitor; $\mathrm{AS}=$ Abono simples; $\mathrm{AQ}=\mathrm{Abono}$ qualificado; SDT $=$ Sem data.

Observações: $\mathrm{a}=\mathrm{A}$ idade sublinhada indica que foi presumida, conforme explicado no texto. $\mathrm{B}=\mathrm{A}$ idade seguida de um sinal de menos (-) indica que há uma excepcionalidade aberta. Nos casos em que foi indicada a idade 16, trata-se da possibilidade de filiação de menores de 16, para exercerem todas as tarefas, exceto as eleitorais. No caso em que foi indicado 18, abre-se a possibilidade excepcional de filiação de maiores de 16. $C=$ Que tenha saído voluntariamente antes ou que tenha tido filiação cancelada. $d=$ Ex-integrantes que tenham sofrido processo condenatório pelo Tribunal de Ética e Disciplina Partidária. e = Indivíduos comprovadamente responsáveis por violação dos direitos humanos, agressão ao meio ambiente ou corrupção, bem como atitudes ou manifestações ofensivas ou discriminatórias à origem étnica, à orientação sexual, de gênero e à crença. $\mathrm{f}=$ Expulsos do partido por deliberação legítima de qualquer órgão de direção partidária; por decisão em última instância foram impedidos de se filiar. $\mathrm{g}=$ Obrigatoriedade de comparecimento à reunião de apresentação da história e concepção do Partido, para confirmação. $\mathrm{h}$ = pagamento de taxa. 
No que tange à possibilidade de cancelamento da filiação partidária, a lei dos partidos políticos prevê cinco formas: morte, perda dos direitos políticos, expulsão, filiação a outro partido e outras. A partir dessas formas básicas, foram identificados outros critérios ou condições para desfiliação, caracterizados como exigências extralegais. Assumiram-se apenas critérios ou condições explicitados nos estatutos, de forma direta9 ${ }^{9}$ Para cada critério ou condição adicional, foi atribuída a pontuação " 3 ", trabalhando-se novamente com um índice somatório simples. Ou seja, quanto maior a pontuação alcançada, mais possibilidades de desfiliação compulsória existem no estatuto do partido. O Quadro 4 apresenta os resultados.

São 14 partidos sem qualquer critério ou condição adicional: DEM, PTC, PMN, PV, PP, PSTU, PCB, PCO, PTN, PSD, PEN, PROS, SD, PCdoB. A todos esses foi atribuída pontuação " 0 ".

Em nove estatutos foi encontrada uma cláusula de absenteísmo. Em alguns casos, a cláusula é bastante definida [ex.: PSDB - faltar a duas convenções consecutivas ou a cinco convocações alternadas], em outros, é vaga [ex.: PDT - evidente desinteresse na militância partidária, reconhecida por decisão do Diretório Estadual ou Nacional]. Três partidos [PTB, PCdoB, PPS] preveem a licença, em alguns casos ligada à possibilidade do absenteísmo sem punição [ex.: PTB - "conceder-se-á licença ao filiado ocupante de cargo partidário: I - por motivo de doença; II - para tratar de interesses particulares"], em outros ligada à evitação da infidelidade partidária, por motivo de consciência [ex: PPS - "o filiado que entender estar sujeito a objeções de consciência, impedimentos ou suspeições poderá requerer à Comissão Executiva correspondente licença por prazo determinado, não superior a 1 (um) ano"].

Seis estatutos (PT, PSB, PSDB, PRTB, PSDC, PR) trazem a previsão de momentos de recadastramento e a obrigatoriedade de atendimento ao próprio, sob pena de desfiliação automática ${ }^{10}$. A convocação de um recadastramento, sob essa condição, é instrumento forte nas mãos de quem tem esse poder. Sintomático dessa situação, o estatuto do PSDB traz uma exceção aos efeitos do recadastramento:

$\S 4^{\circ}$. Não se aplicam as disposições dos parágrafos anteriores aos filiados que prestem ou tenham prestado relevantes serviços ao PSDB ou que a 
Comissão Executiva considere a manutenção de sua filiação de relevante interesse para o Partido; (...) $§ 6^{\circ}$. Estão dispensados de comparecer ao recadastramento a que se refere o inciso $\mathrm{V}$ e o $\S 5^{\circ}$, os filiados que ocupem qualquer cargo partidário ou eletivo ou que tenham menos de 2 (dois) anos de filiação.

Trata-se explicitamente de regra não aplicável aos "amigos".

Os estatutos do PRP, PHS, PSDC, PRB e PSOL trazem cláusulas de inadimplência. O PPS e o PSL adotam a possibilidade de expulsão discricionária por "decisão política da Comissão Executiva Nacional, ad referendum do Diretório Nacional". O PSDC traz cláusulas curiosas de fidelidade eleitoral (que pode ser entendida como uma dimensão da fidelidade partidária):

art. 69 , $9^{\circ}$. São motivos suficientes para justificar a expulsão de filiado, sem prejuízos de outros: (...) II. nas eleições proporcionais, deixar de votar em candidatos Filiados ao Partido, admitida como prova da infidelidade partidária não constar dos resultados, na seção eleitoral em que votou o filiado, pelo menos um voto para os candidatos Filiados ao Partido, em cada cargo para o qual concorrer, admitido o voto na legenda do Partido, para caracterizar a fidelidade partidária; III. nas eleições majoritárias, deixar de votar em candidato próprio do Partido ou em candidato por ele formalmente apoiado em Convenção Partidária, valendo como prova da infidelidade partidária não constar nos resultados, na seção eleitoral em que votou o filiado, nenhum voto para aquele candidato.

O PRTB e o PHS adotam o critério de "promover ação na justiça contra o partido". Seja de inspiração bíblica (se um irmão pecar contra ti, vai com dois outros irmãos e tente resolver diretamente com ele) ou popular (roupa suja se lava em casa), é o princípio de que a resolução de conflitos entre membros de uma associação deve se dar dentro da própria e segundo as suas regras. 
Quadro 4

Partidos Políticos. Critérios Extralegais de Desfiliação.

\begin{tabular}{|c|c|}
\hline Sigla & Critério / Condição \\
\hline PMDB & $\begin{array}{l}\text { Cláusula de absenteísmo } \\
\text { Cláusula de inadimplência } \\
\text { Condenação por crime infamante ou } \\
\text { por práticas administrativas ilícitas, com sentença tramitada em julgado }\end{array}$ \\
\hline РTB & $\begin{array}{l}\text { Cancelamento da naturalização } \\
\text { Cláusula de absenteísmo }\end{array}$ \\
\hline PDT & Cláusula de absenteísmo \\
\hline PT & Cláusula de recadastramento \\
\hline PSB & Cláusula de recadastramento \\
\hline PSDB & $\begin{array}{l}\text { Cláusula de absenteísmo } \\
\text { Cláusula de recadastramento } \\
\text { Condenação com sentença transitado em julgado ou } \\
\text { perda de mandato por falta de decoro parlamentar }\end{array}$ \\
\hline PSC & $\begin{array}{l}\text { Comportamento público e notório que atente contra a imagem, Programa, } \\
\text { Manifesto, Estatuto, Diretrizes, Resoluções, Deliberações, Orgãos e Dirigentes } \\
\text { do PSC }\end{array}$ \\
\hline PRP & $\begin{array}{l}\text { Cláusula de inadimplência } \\
\text { Filiado detentor de mandato eletivo que usar o erário público para } \\
\text { fins particulares e pessoais, bem como ser penalizado por crime de } \\
\text { responsabilidade, peculato ou improbidade administrativa, com sentença } \\
\text { transitada em julgado }\end{array}$ \\
\hline PPS & $\begin{array}{l}\text { Decisão política da Comissão Executiva Nacional, ad referendum do Diretório } \\
\text { Nacional }\end{array}$ \\
\hline PTdoB & Cláusula de absenteísmo \\
\hline PRTB & $\begin{array}{l}\text { Promover ação na justiça contra o partido } \\
\text { Cláusula de recadastramento }\end{array}$ \\
\hline PHS & $\begin{array}{l}\text { Cláusula de inadimplência } \\
\text { Cláusula de absenteísmo } \\
\text { Promover ação na justiça contra o partido }\end{array}$ \\
\hline PSDC & $\begin{array}{l}\text { Cláusula de recadastramento } \\
\text { Cláusula de absenteísmo } \\
\text { Cláusula de inadimplência } \\
\text { Infidelidade "eleitoral" }\end{array}$ \\
\hline PSL & $\begin{array}{l}\text { Decisão política da Comissão Executiva Nacional, ad referendum do Diretório } \\
\text { Nacional } \\
\text { Infidelidade partidária }\end{array}$ \\
\hline PRB & $\begin{array}{l}\text { Cláusula de inadimplência } \\
\text { Desobediência ao calendário nacional definido pela Comissão Executiva } \\
\text { Nacional para as Convenções para eleição do Diretório }\end{array}$ \\
\hline
\end{tabular}


Quadro 4

Partidos Políticos. Critérios Extralegais de Desfiliação.

\begin{tabular}{|c|c|}
\hline Sigla & Critério / Condição \\
\hline PSOL & Cláusula de inadimplência $^{\mathrm{a}}$ \\
\hline PR & $\begin{array}{l}\text { Cláusula de recadastramento } \\
\text { Cláusula de absenteísmo }\end{array}$ \\
\hline PPL & Cláusula de absenteísmo \\
\hline
\end{tabular}

Fonte: Elaborado pelos autores, com base nas informações dos estatutos partidários.

$\mathrm{a}=$ reincidência reiterada. $\mathrm{b}=$ indicado no estatuto "caducidade", o que foi interpretado como um tipo de recadastramento.

O Quadro 5 apresenta a classificação dos autores em relação aos partidos, no tocante à desfiliação, agrupando-os em "brandos", "rigorosos" e "severos". À primeira vista, não há explicação que justifique a formação dos grupos abaixo. Entretanto, há de se ressaltar que em sua maioria os partidos brasileiros são brandos em relação aos critérios de desfiliação. Somando severos e rigorosos não se chega à metade deles. Entre os severos destaca-se a presença do PSDB, como participante do quadro dos principais partidos do país.

Quadro 5

Partidos Políticos. Critérios de Desfiliação. Consolidação

\begin{tabular}{ccc}
\hline Brandos & Rigorosos & Severos \\
$0 \vdash 4$ & $5 \vdash 9$ & $10 \vdash$ \\
\hline DEM, PTC, PMN, PMN, PV, PP, & & \\
PSTU, PCB, PCO, PTN, PSD, & PMDB, PTB, PRP, PRTB, & PSDB, PSDC \\
PEN, PROS, SD, PDT, PT, PSB, & PHS, PSL, PRB, PR & \\
PSC, PPS, PTdoB, PSOL, PPL & & \\
\hline Fonte: Elaborado pelos autores, com base nos resultados do índice construído para a dimensão desfiliação.
\end{tabular}

Na maioria (20) dos partidos, as regras de adesão são simples e não há grande preocupação com regras adicionais de exclusão. Portanto, é fácil entrar, manter-se e sair do partido. Em um contexto de partidos voltados para competição eleitoral, de fato não há necessidade de dificultar o acesso e a mudança de filiados. Muito provavelmente, essas regras refletem a queda do número de filiados pelo mundo, já que a força do partido não se foca da mesma forma neste quesito. Dados recentes mostram uma razoável queda (de cerca de 5 pontos percentuais) nas filiações em 13 democracias europeias consolidadas, nos últimos 30 anos (Van Biezen, Mair, Poguntke, 2012). Outra evidência desse fato é apresentada por pesquisa nos websites dos partidos brasileiros (Barros, Rodrigues e Martins, 2015), que mostram não haver interesse em recrutamento, pelo menos por meio digital. Apesar de não ser o propósito deste artigo levantar 
dados quantitativos de filiação para o caso brasileiro, é interessante o achado de que, do ponto de vista normativo, confirma-se o pouco interesse dos partidos em relação à questão da filiação, o que dialoga com a perspectiva do partido cartel de Katz e Mair (1995).

As evidências encontradas com relação a filiações e desfiliações trazem à baila algumas questões importantes. Em primeiro lugar, há que se pensar em que medida as regras estatutárias são efetivamente elaboradas para cumprir um determinado papel - se realmente dialogam com algum grupo central que as operacionalizam para proteger seu poder dentro do partido. Ainda que não seja assim na sua gênese, pode ser que essas regras sejam deliberadamente pensadas e adotadas diante de situações importantes, do que há indícios nas constantes alterações estatutárias promovidas pelos partidos, como será demonstrado.

A segunda questão diz respeito à importância da filiação. A literatura atual sobre partidos políticos questiona se um grande número de filiados é importante para os partidos. O conceito de partido cartel supõe que filiados não são importantes porque o partido já conta com recursos públicos para a campanha (tempo de TV e rádio, fundo partidário).

\section{ORGANIZAÇÃO E ESTRUTURA INTERNA}

Do ponto de vista geográfico, os partidos se organizam em um modelo conexional, com a autonomia de cada nível sendo condicionada por restrições às competências decisórias, elementos de compulsoriedade comportamental e possibilidade de intervenção direta ${ }^{11}$. Há claramente organização interna de alta intensidade, com forte articulação estrutural entre as instâncias partidárias, características de partidos de massa, conforme previsto por Duverger (1980) e comprovado por Janda e King (1985). Ribeiro também compartilha desse achado:

não é mais suficiente reproduzir o lugar-comum segundo o qual os partidos brasileiros seriam altamente descentralizados, com seções locais e estaduais completamente independentes frente a órgãos nacionais praticamente inexistentes (Ribeiro, 2013:254). 
Verifica-se a predominância de duas configurações-tipo: uma com quatro níveis e outra com três. O Quadro 6 apresenta essas configurações e os respectivos partidos.

Quadro 6

Partidos - Configurações organizacionais - Dimensão Geográfica

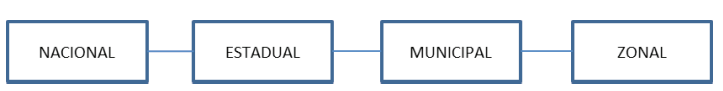

PMDB,PDT*,PT,PCdoB*,PSB,PSDB

PTC,PPS,PV*,PP,PCB*,PSDC,PRB,

$\mathrm{PR}^{*}, \mathrm{PPL}$

Total: 15 partidos

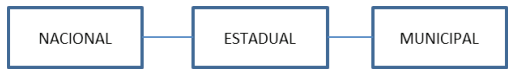

PTB,DEM,PSC,PMN,PRP,PTdoB,

PSTU,PRTB*,PHS,PCO,PTN*,PSL,

PSOL,PSD,PEN,PROS,SD

Total: 17 partidos

Fonte: Elaborado pelos autores, com base nas informações dos estatutos partidários.

* Os partidos assinalados, na linha de quatro níveis, são aqueles que, apesar de terem os quatro níveis, adotam denominações diferenciadas para algum dos níveis. Idem com relação aos partidos de três níveis.

A configuração-tipo de quatro níveis abrange a questão dos grandes municípios, possibilitando maior capilaridade organizativa ao estabelecer os órgãos "zonais". A variante mais frequente é a utilização da denominação regional ao invés de estadual (PV, PCB, PRTB, PTN). Excetuando-se o PV, a opção pela nomenclatura não deixa claro se é mera escolha estilística ou busca de flexibilidade ${ }^{12}$. Ribeiro (2013) alerta para a manutenção de características que eram impositivas na antiga Lei Orgânica dos Partidos Políticos - Lei no 5.682/1971 (LOPP), apesar da autonomia organizativa adquirida na nova legislação (Lei no 9.096/95):

os estatutos partidários pós-1995 continuaram parecidos em relação aos que vigoravam sob a vigência da LOPP. As mudanças realizadas foram pontuais, alterando, acrescentando ou suprimindo pontos em cima dos textos anteriores (Ribeiro, 2013:238).

Entre os elementos que permaneceram da LOPP, está a organização partidária em termos geográficos, uma vez que a estrutura prevista pela LOPP refletia a organização federalista nacional (idem).

Do ponto de vista hierárquico, o tipo predominante é a organização em três níveis, sendo um deliberativo, um diretivo e um de ação. $\mathrm{O}$ 
Quadro 7 apresenta as principais configurações existentes e os respectivos partidos.

Quadro 7

Partidos - Configurações organizacionais - Dimensão hierárquica - Nível nacional
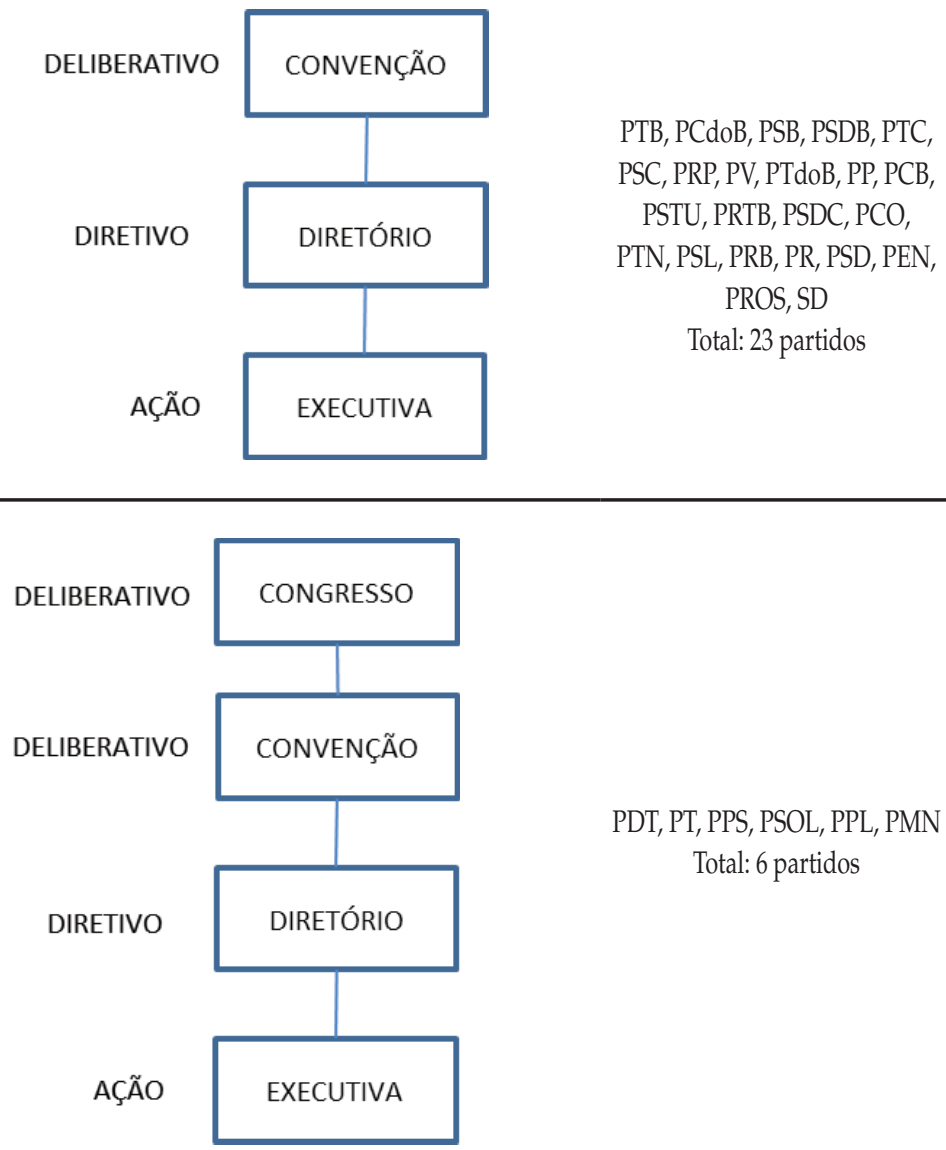

Fonte: Elaborado pelos autores, com base nas informações dos estatutos partidários. Faltam na lista PMDB, DEM E PHS, cujas situações são tratadas adiante no artigo.

A principal diferença entre o tipo predominante (3 níveis) e a principal variante (4 níveis) é a previsão explícita do Congresso partidário como órgão, com competências não muito claramente definidas ${ }^{13}$, porém "mandatárias ao partido" (PDT, art. 27, §3ㅜㅜ).

O Quadro 8 apresenta dados quantitativos sobre membros nos diretórios. 
Quadro 8

Diretórios partidários. Quantidade de membros

\begin{tabular}{cccc}
\hline & Nacional & Estadual & Municipal \\
\hline Média & 107,5 & 57,2 & 34 \\
Mínimo & 33 & 17 & 9 \\
Máximo & 350 & 141 & 101 \\
\hline
\end{tabular}

Fonte: Elaborado pelos autores, com base nas informações estatutárias dos partidos. Considerado o número máximo possível de membros indicado pelo dispositivo estatutário.

Percebe-se, pelos valores médios, bem como pelos valores máximo e mínimo de membros encontrados nos diretórios, que se trata de órgãos assembleísticos, com pouca probabilidade de exercer efetivamente a condução das atividades diárias dos partidos.

O Quadro 9 apresenta dados sobre a quantidade de membros nas comissões executivas.

Quadro 9

Comissões Executivas. Quantidade de Membros

\begin{tabular}{cccc}
\hline & Nacional & Estadual & Municipal \\
\hline Média & 22,7 & 12,8 & 8,3 \\
Mínimo & 9 & 5 & 5 \\
Máximo & 100 & 25 & 18 \\
\hline
\end{tabular}

Fonte: Elaborado pelos autores, com base nas informações estatutárias dos partidos. Considerado o número máximo possível de membros indicado pelo dispositivo estatutário.

Os valores médios encontrados para as comissões executivas demonstram que se trata de órgãos com possibilidade de operacionalizarem atuação conjunta com vistas à execução de fato. Apesar da média para as comissões executivas nacionais estar acima do grupo simpatético $[22,7]^{14}$, ainda é um valor bem mais próximo do que os verificados para os diretórios. O grupo simpatético envolve, por exemplo, pedir aos indivíduos para se lembrarem de pessoas cuja morte seria devastadora para eles [11-12] ou amigos e colegas com os quais tiveram contato pelo menos uma vez no mês [10-15] (Dunbar, 1998:77). Para Dunbar,

é surpreendente que grupos deste tamanho sejam comuns em situações em que grande coordenação de comportamento é requerida: os júris, os gabinetes internos de muitos governos, o número de apóstolos, o tamanho da maioria das equipes de esporte $(1998: 77)^{15}$.

Matematicamente, o número ideal de membros implica uma maximização de uma função em que se levam em consideração a quantidade 
de membros, a possibilidade de os membros atuarem efetivamente na solução de problemas e o custo de se ter um número determinado de membros. Essa perspectiva indica que o retorno marginal de aumentar a quantidade de membros é decrescente.

Verifica-se aqui um elemento altamente concentrador de poder, uma vez que as comissões executivas enfeixam competências amplas e são, na prática, o órgão máximo dos partidos nos interregnos das reuniões dos demais órgãos (diretórios e convenções). Além disso, as comissões executivas detêm a competência de convocação e presidência dos respectivos diretórios e convenções, outro indicativo de concentração de poder. Esse achado dialoga com a previsão de Duverger:

o comitê define-se inicialmente pelo seu caráter restrito. (...) em que pese a fraqueza numérica, o comitê pode dispor, não obstante, de grande poder. Sua força não repousa, com efeito, na quantidade de seus membros, porém na sua qualidade. Constitui ele um agrupamento de pessoas importantes, escolhidas em razão de sua influência. (1980:53)

Continuando seu raciocínio, Duverger (1980) ressalta que a organização dos partidos políticos não se conforma à democracia, antes, à autocracia e à oligarquia e que o processo de escolha dos 'chefes' partidários leva à formação de uma "casta mais ou menos fechada sobre si mesma" (Idem:455). Ou, nas palavras de Sartori (1982), é no âmbito da organização dos partidos, sobretudo no processo de escolha e operação dos seus órgãos dirigentes, que se dá a chamada política invisível. A formatação da organização - órgãos deliberativos e diretivos com composição assembleística e reuniões esporádicas; órgãos executivos com reuniões constantes e poderes plenos nos interregnos - faz com que não se aplique, prima facie, a lógica da teoria da agência. Não há precisamente assimetria de poder entre o principal (convenções, diretórios) e o agente (executivas), uma vez que são as executivas que "comandam" (convocam, presidem) os diretórios e as convenções, configurando relações de contra agência, por assim dizer.

Outro mecanismo de perfil notadamente oligárquico é a manutenção de intrincada rede de membresias nativas nos órgãos partidários. No caso das Executivas Nacionais, por exemplo, verifica-se que em 23 partidos os líderes das bancadas na Câmara dos Deputados e no Senado Federal são arrolados como membros natos. Há situações de presença intercruzada descendente (membros do Diretório Nacional 
presentes como membros natos nos Diretórios Estaduais e Municipais nos quais tenham domicílio eleitoral) e ascendente (presidentes de Comissões Executivas Estaduais presentes no Diretório Nacional). Além disso, são encontrados como membros natos, ex-presidentes do partido, presidentes de honra, presidentes dos movimentos partidários organizados (Juventude, Mulheres etc.), presidentes dos Conselhos Políticos, membros do Executivo em cada nível (Presidente e Vice-Presidente da República, Governador e Vice-Governador, Prefeito e Vice-Prefeito, Ministros de Estado). Excetuam-se à existência de membresias nativas o PCdoB, PCB, PSTU, PCO e PSOL, todos partidos no espectro mais à esquerda, o que pode significar, pelo menos do ponto de vista estatutário e no ponto em tela, um compromisso maior desses com práticas democráticas de seleção de lideranças.

Há dois partidos - PMDB, DEM - que adotam o tipo de quatro níveis, sendo um dos níveis, contudo, ocupado por um Conselho Político. Há dois outros partidos (PDT, PSDB) que adotam a figura do Conselho Político, porém de forma lateral na hierarquia. Trata-se de órgão composto por pessoas tradicionais nos partidos e com competências ambíguas, porém também vinculantes, o que é um marcador de controle oligárquico. O Quadro 10 apresenta a composição e as competências previstas para esse Conselho, nos casos em que existe. Percebe-se que se trata tanto de uma reserva de vagas para políticos de expressão no partido quanto de reserva de poderes de decisão genéricos. Ribeiro também encontrou nos Conselhos Políticos do DEM e do PSDB indícios de uma "sensível concentração decisória das máquinas, na medida em que concedeu extensos poderes a órgãos totalmente (ou quase) compostos por membros não eleitos pelo corpo partidário" (2013:246). 
Quadro 10

Conselhos Políticos. Composição e Competências.

\begin{tabular}{|c|c|c|}
\hline Partido & Composição & Competências \\
\hline PMDB & $\begin{array}{l}\text { - membros da Comissão Executiva } \\
\text { Nacional; } \\
\text { - presidentes dos Diretórios Estaduais; } \\
\text { - ex-Presidentes Nacionais; } \\
\text { - ex-Presidentes da República; } \\
\text { - Governadores de Estado; } \\
\text { - Presidentes da Câmara dos } \\
\text { Deputados e Senado Federal; } \\
\text { - ex-Presidentes da Câmara e do } \\
\text { Senado Federal } \\
\text { - ex-Líderes do Partido nestas duas } \\
\text { Casas. }\end{array}$ & $\begin{array}{l}\text { - tornar mais ágeis as mais importantes decisões } \\
\text { partidárias, sem perda da representatividade do } \\
\text { Partido; } \\
\text { - julgar os recursos que lhe sejam interpostos de } \\
\text { atos e decisões da Comissão Executiva Nacional } \\
\text { ou dos Diretórios Estaduais; } \\
\text { - elaborar o seu Regimento Interno; } \\
\text { - promover a responsabilidade dos Diretórios } \\
\text { Estaduais, e, na omissão destes, dos Municipais } \\
\text { e Zonais, decidindo sobre sua dissolução, } \\
\text { intervenção e reorganização; } \\
\text { - traçar a linha política e parlamentar de âmbito } \\
\text { nacional a ser seguida pelos representantes do } \\
\text { partido; } \\
\text { - definir, extraordinariamente, a posição e a linha } \\
\text { do Partido em situações políticas específicas não } \\
\text { abrangidas por decisões anteriores dos órgãos } \\
\text { partidários; } \\
\text { - fixar as datas das Convenções Ordinárias dos } \\
\text { órgãos partidários, bem como prorrogar por até } \\
\text { um ano os mandatos dos seus membros; } \\
\text { - regulamentar, por Resoluções, disposições } \\
\text { deste Estatuto. }\end{array}$ \\
\hline DEM & $\begin{array}{l}\text { - Presidente Nacional do Democratas; } \\
\text { - ex-Presidentes do Partido; } \\
\text { - Governadores; } \\
\text { - Prefeitos de capitais; } \\
\text { - Líderes na Câmara dos Deputados e } \\
\text { no Senado Federal; } \\
\text { - até seis membros eleitos em } \\
\text { Convenção dentre os ex-Governadores, } \\
\text { ex-Ministros de Estado, ex-líderes no } \\
\text { Congresso Nacional e ex-Prefeitos de } \\
\text { Capital. }\end{array}$ & $\begin{array}{l}\text { - decidir soberanamente sobre a linha partidária, } \\
\text { bem como sobre a possibilidade de participação } \\
\text { do Democratas na Administração Pública, } \\
\text { ouvida a Comissão Executiva Nacional; } \\
\text { - recomendar sobre coligações para as eleições } \\
\text { nacionais e estaduais, bem como propor, à } \\
\text { Convenção Nacional, os candidatos a Presidente } \\
\text { e Vice-Presidente da República. }\end{array}$ \\
\hline
\end{tabular}


Quadro 10

Conselhos Políticos. Composição e Competências.

\begin{tabular}{|c|c|c|}
\hline Partido & Composição & Competências \\
\hline PDT & $\begin{array}{l}\text { - Presidente do partido; } \\
\text { - Vice-Presidentes do partido; } \\
\text {-Secretário Nacional do partido; } \\
\text { - Líderes na Câmara e no Senado; } \\
\text { - Presidente da Fundação Alberto } \\
\text { Pasqualini; } \\
\text { - Presidente da República; } \\
\text { - ex-Presidente da República; } \\
\text { - Governadores; } \\
\text { - ex-Governadores; } \\
\text { - } 10 \text { membros de notória fidelidade } \\
\text { aos ideais partidários e experiência } \\
\text { política, eleitos pelo Diretório } \\
\text { Nacional. }\end{array}$ & $\begin{array}{l}\text { - opinar sobre temas de relevante importância } \\
\text { para o Partido e a Nação; } \\
\text { - elaborar documentos doutrinários; } \\
\text { - formular sugestões de modificação dos } \\
\text { Estatutos e Programa Partidários; } \\
\text { - analisar políticas de governo no âmbito federal } \\
\text { e a conjuntura internacional e recomendar à } \\
\text { Executiva Nacional decisões ou medidas que } \\
\text { considere oportunas. }\end{array}$ \\
\hline PSDB & $\begin{array}{l}\text { - ex-Presidentes da República e os que } \\
\text { tenham concorrido ao cargo; } \\
\text { - um representante dos Governadores } \\
\text { de Estado; } \\
\text { - um representante das bancadas do } \\
\text { Congresso Nacional; } \\
\text { - o Presidente da Comissão Executiva } \\
\text { Nacional. }\end{array}$ & $\begin{array}{l}\text { - avaliar periodicamente o desempenho político } \\
\text { do Partido; } \\
\text { - atuar, conjuntamente com o Diretório Nacional, } \\
\text { no exame e decisão de questões políticas } \\
\text { relevantes de âmbito nacional que lhe forem } \\
\text { submetidas pela Comissão Executiva Nacional; } \\
\text { - decidir, no âmbito da eleição majoritária } \\
\text { nacional, sobre o modelo de escolha de } \\
\text { candidatos e a formação de coligação, assim } \\
\text { como sobre fusões ou incorporações partidárias, } \\
\text { que lhe forem submetidos pela Comissão } \\
\text { Executiva Nacional. }\end{array}$ \\
\hline
\end{tabular}

Fonte: Elaborado pelos autores, com base nas informações dos estatutos partidários.

O PHS é um caso único. Está previsto na organização do partido um "Conselho Gestor Nacional", da seguinte forma:

37. O Conselho Gestor Nacional é órgão de deliberação superior ao qual os demais órgãos devem submeter suas decisões para validação. 38. Compete privativamente ao Conselho Gestor Nacional: I - revogar as decisões das convenções de todos os níveis que contrariem as decisões do próprio Conselho; II - decidir, em última instância, em grau de recurso; III - aprovar os nomes propostos para composição da CEN e demais órgãos 
nacionais; IV - propor quaisquer alterações normativas e estatutárias para consecução dos objetivos do partido.

São quatro membros, com mandato de dez anos, que só podem ser destituídos por decisão da maioria absoluta do próprio Conselho. Percebe-se que o partido alcançou um nível extremo em termos de ausência de democracia interna.

No nível municipal, cinco partidos adotam uma configuração organizacional de quatro níveis, agregando os chamados Núcleos de Base como nível hierarquicamente inferior. Apesar de não explicitarem os núcleos de base como órgão, outros partidos os preveem explicitamente em seus estatutos. Os núcleos de base são o equivalente às células, previstas por Duverger (1980), espaços com número reduzido de membros, contato frequente, mobilização constante, devendo ser elemento dinamizador dos partidos políticos ${ }^{16}$.

Os achados sobre organização e estrutura interna, portanto, refletem a posição central da obra de Michels (1949), de que, apesar de existir uma fachada democrática, há caracteres autoritários na estrutura interna dos partidos. Esse fenômeno, em Michels (1949), é quase que naturalizado (necessidade de liderança), refletindo a tensão permanente entre democracia-participação e autocracia-governo (e estabilidade de pequenos grupos). Apesar dos partidos se assumirem sempre como democráticos, deve-se considerar que o esforço do ator individual é sempre para alcançar e manter posições assimétricas de poder em seu benefício, ainda que para ser árbitro dos movimentos entre os grupos. A configuração estrutural (poucos níveis hierárquicos com vinculação forte entre si), a distribuição de competências (relações de contra agência), a força dada a grupos pequenos (Executivas) diante de grupos grandes (Congressos), são elementos confirmadores dessas práticas.

\section{DIRIGENTES PARTIDÁRIOS}

Duverger aponta que

a organização dos partidos políticos, certamente, não se conforma à ortodoxia democrática. A respectiva estrutura interna é, essencialmente, autocrática e oligárquica; os chefes não são, de fato, designados pelos 
adeptos, apesar da aparência, mas cooptados ou nomeados pelo centro; tendem a formar uma classe dirigente isolada dos militantes, casta mais ou menos fechada sobre si mesma. (1980:455)

Em Duverger (1980) e em Sartori (1982) esse fato é apontado como algo quase espontâneo. Em Michels (1949) aparece quase como uma "lei da natureza". Michels parte da necessária divisão do trabalho que acompanha o crescimento da organização e trabalha com variáveis técnicas (ganhos cognitivos com a especialização da atividade, o que geraria a indispensabilidade técnica da liderança) e psicológicas (transformações comportamentais causadas pelo exercício da liderança). Apesar de avançar mais do que Duverger e Sartori, Michels permanece ainda no plano de compreender esse processo como natural e suas causas técnicas e psicológicas seriam suficientes como fatores explicativos da oligarquização nos partidos. Medding (1980), um dos críticos ao trabalho de Michels, afirma que ele teria se limitado a simplesmente rotular a liderança do partido como uma elite, inspirado pela teoria das elites de Mosca (2009). De fato, Michels debruçou-se sobre um partido em específico, no contexto europeu, o qual tinha acompanhado desde o nascimento e, portanto, era testemunha das transformações que analisou. E, na época em que escreveu, os partidos políticos, de uma forma geral no contexto internacional, principiavam sua inserção no universo político. De qualquer forma, já previa uma certa autonomização das elites em relação às bases, o que também aparece na queda de filiação ligada às mudanças nas próprias funções dos partidos (mais eleitorais).

As causas apontadas por Michels (1949) podem ser identificadas como causas originárias do processo de oligarquização. Na presente pesquisa, contudo, verifica-se que houve uma institucionalização das práticas, mobilizadas para manutenção do controle do partido por uma pequena elite dirigente, com a inscrição dessas técnicas na forma de regras estatutárias. A partir disso, a própria regra gera o comportamento e se torna também mais um fator causal e explicativo. Assim, avança-se um passo a mais no desafio de demonstrar não só que a liderança existe, mas como opera a conquista e permanência na liderança. Esse achado é compartilhado por Ribeiro: "em geral, os sistemas políticos intrapartidários mantiveram-se pouco inclusivos, favorecendo parlamentares e dirigentes em detrimento da base" (2013:246).

Com relação à forma de escolha dos dirigentes partidários, verifica-se que a quase totalidade dos partidos $\left(31^{17}\right)$ adota um sistema indi- 
reto de eleições. Duverger (1980:185) afirma que "o sufrágio indireto constitui admirável meio de por de lado a democracia fingindo aplicá-la". No caso da eleição para as comissões executivas nacionais, por exemplo, o processo típico abrange quatro etapas eleitorais, conforme demonstrado pela Figura 1. Variações no processo típico incluem, de fato, mais etapas ainda ao processo, como a inclusão dos Diretórios: Convenção Municipal elege Diretório Municipal que elege candidatos à Convenção Estadual que elege Diretório Estadual e assim por diante, como é o caso do PDT, por exemplo.

Figura 1

Processo Típico de Eleição de Comissão Executiva Nacional. Diagrama

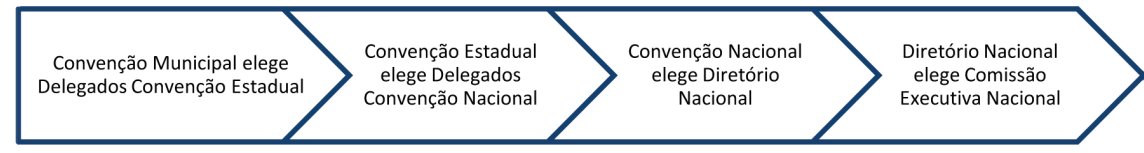

Fonte: Elaborada pelos autores.

Em processos eleitorais indiretos, há no máximo uma tênue ligação entre o resultado eleitoral e a massa de filiados. A recorrente exigência de chapas para o processo eleitoral associa-se ao procedimento eleitoral indireto, como outra restrição à livre escolha do eleitor (27 partidos a adotam. Exceções: PCdoB, PSB, PHS, PCO, PPL $\left.{ }^{18}\right)$. A chapa, do ponto de vista de quem deseja se candidatar, significa, minimamente, já ter uma rede de contatos estabelecida no partido, bem como, muitas vezes, conseguir o apoio mínimo de um número expressivo de outros filiados, funcionando como forte barreira de entrada. Do ponto de vista eleitoral, tem efeitos similares ao da lista fechada ${ }^{19}$ em sistemas eleitorais proporcionais, como o de permitir um maior controle por parte dos grupos dominantes no partido, enquanto restringe a livre escolha do eleitor.

A massiva predominância do sistema eleitoral indireto e da obrigatoriedade da chapa corrobora as previsões de Duverger (1980), Sartori (1982) e Michels (1949). Michels assinalava que "em todos os partidos insinuou-se o sistema eleitoral indireto, que, na vida pública, os partidos democráticos combatem com vigor" (1949:368). Sartori destaca que o militante depende essencialmente do sistema eleitoral intrapartidário, pois dele depende vitalmente a sua carreira:

as disposições eleitorais intrapartidárias constituem, para o político que visa a uma carreira, o caminho para chegar aos cargos, ou o caminho para 
o sucesso (...) a variável do sistema eleitoral é muito mais poderosa nas questões intrapartidárias do que em outras (Sartori, 1982:121).

Duverger, ao apreciar o sistema eleitoral indireto aplicado intrapartidariamente, afirma que "tais são os fundamentos econômicos do 'bossism': uma machine, isto é, uma organização irregular que domina efetivamente um partido, constitui essencialmente uma empresa para a conquista de postos e de vantagens legais e ilegais que podem adquirir; o boss é o chefe e o criador dessa empresa" (Duverger, 1980:185). Ou seja, dado que os partidos são importantes para as carreiras políticas, a carreira dos políticos depende dos partidos e, portanto, a conquista e a manutenção do controle sobre as estruturas partidárias tornam-se variáveis-chave.

Duverger e Sartori, assim como Michels, olham partidos europeus em uma época distante da atual. A marca dessa reflexão, centrada na Europa, é que os partidos eram canais centrais e inescapáveis para a viabilidade política dos postulantes. O Brasil, contudo, apresenta elementos distintos. No país, ainda se verifica a possibilidade de outsiders na política - comum no caso de cargos legislativos, mas possível inclusive para cargos majoritários, como foi o caso da eleição presidencial vencida por Fernando Collor, filiado a partido irrelevante. Uma das críticas da literatura sobre o funcionamento parlamentar brasileiro é a dificuldade de os líderes controlarem suas bancadas, o que teria, como uma das raízes, a falta de controle dos partidos brasileiros sobre o processo eleitoral de seus membros (por exemplo, Ames, 2003). Assim, vê-se que o partido no Brasil muitas vezes pode ser "contornado" pelos postulantes, funcionando a legenda apenas como um requerimento formal de uma candidatura que se move pelas suas próprias forças. Uma consequência importante, com efeitos sobre a coesão partidária é que o sucesso em campanhas (muitas vezes individualistas) permite o acesso do eleito a postos na estrutura partidária como membro nato, devido ao seu posto eletivo. Neste segundo aspecto vê-se mais um elemento de distinção, no sentido de fraqueza, dos partidos brasileiros em relação aos partidos europeus que foram objeto de análise pelos autores clássicos citados.

Outro mecanismo de controle do acesso aos quadros dirigentes partidários é a exigência de pré-requisitos aos candidatos, sendo os mais comuns a obrigatoriedade de estar em dia com as obrigações financeiras (32 partidos) e o tempo mínimo de filiação (16 partidos). 
Com relação a esse último, há desde os tempos mínimos (contados em dias: 5 dias - DEM, PTC; 10 dias - PTdoB; 15 dias - PDT, PSDC; 30 dias - PP, PEN,SD) até tempos maiores (6 meses - PMDB, PSDB, PSC, PCB; 1 ano - PT, PMN, PRTB; 2 anos - PROS). O PROS é o único a apresentar um pré-requisito similar ao ficha limpa ${ }^{20}$. Em alguns casos, são apresentados pré-requisitos genéricos, em dispositivos de interpretação ambígua que permitem aplicação discricionária (PDT, PT, PCdoB, PHS, PPL ${ }^{21}$ ).

Esses achados dialogam com o trabalho de Ribeiro (2013), no tocante à dimensão de inclusividade. Esse autor encontrou inclusividade baixa na formação das Executivas de DEM, PSDB e PMDB; e inclusividade baixa-média na formação dos Diretórios desses mesmos partidos (Ribeiro, 2013:256). A baixa inclusividade tem como contrapartida o aumento da autonomia decisória das cúpulas dirigentes. Isso explica, por exemplo, a existência dos chamados "caciques" partidários.

Com relação aos mandatos, há uma variação de dois anos a mandatos por tempo indeterminado (PMN) e a possibilidade total de reeleição 22 . Além da reeleição indefinida, há, em muitos casos, a previsão expressa de prorrogação dos mandatos, por igual período, sem novas eleições. O que mais uma vez reforça a perpetuação de caciques, pois explica como conseguem se tornar profissionais da política. Ao poderem deter o comando dos partidos ad eternum, conseguem garantir estrutura de base fundamental para estratégias de perpetuação de mandatos ou cargos políticos.

\section{ALTERAÇÕES ESTATUTÁRIAS}

O termo estatuto compartilha origens com estátua ${ }^{23}$. Presume-se, portanto, que esteja relacionado à estabilidade, definido para ser perene. No sentido a ser estudado no presente artigo, o termo se refere a uma normatividade que rege um grupo de pessoas. Criam-se associações por adesão e as pessoas aderem a uma normatividade específica, que estabelece regras de convivência para os aderentes.

Os estatutos instauram um segmento próprio de direito, universalizando para uma dada comunidade (os associados) os pressupostos de procedimentos, comportamentos, direitos e deveres daquela associação. Por serem firmes e explícitos, retiram dos indivíduos que 
fazem parte daquela associação o fardo de buscarem constantemente validade para seus atos. Da mesma forma que a lei, os estatutos geram previsibilidade comportamental, restritos, todavia, ao âmbito dos associados.

No caso dos partidos políticos, há uma compreensão clara de que os estatutos fazem parte do processo fundacional dos próprios. Há a previsão constitucional de registro dos estatutos junto ao Tribunal Superior Eleitoral como parte do ato administrativo complexo de criação de um partido ( $\mathrm{CF}$, art. $\left.17, \S 2^{\circ}\right)$. A lei dos partidos políticos (Lei no 9.096/95) também faz menção aos estatutos em diversos momentos, dentre os quais se destaca o $\$ 2^{\circ}$ do art. 7ㅇ, que define que somente o partido com estatuto registrado pode "participar do processo eleitoral, receber recursos do Fundo Partidário e ter acesso gratuito ao rádio e à televisão".

Apesar dessa importância, apenas em um caso há uma previsão expressa de que o conhecimento do estatuto do partido deve ser prévio à filiação, $\mathrm{o} \mathrm{PCB}^{24}$. De certo modo, a pouca importância dada ao conhecimento do Estatuto dialoga com a perspectiva de desideologização do discurso partidário, presente na conceituação dos partidos catch all, de Kirchhemeir (2012).

Registrando o prazo de vigência dos estatutos dos partidos políticos, chega-se ao Quadro 11.

Quadro 11

Estatutos Partidos Políticos. Alterações.

\begin{tabular}{|c|c|c|c|c|}
\hline Sigla & Datas & Alterações & Intervalos* & $\begin{array}{c}\text { Intervalos / } \\
\text { alterações }\end{array}$ \\
\hline SD & $7 / 11 / 2012 ; 27 / 9 / 2013$ & 1 & 320 & 320 \\
\hline PHS & $\begin{array}{c}12 / 12 / 1995 ; 24 / 8 / 1997 ; \\
9 / 1 / 2000 ; 16 / 12 / 2001 ; \\
22 / 11 / 2003 ; 29 / 5 / 2005 ; \\
13 / 1 / 2007 ; 28 / 7 / 2007 ; \\
27 / 4 / 2008 ; 28 / 3 / 2009 ; \\
14 / 11 / 2009 ; 22 / 1 / 2011 ; \\
29 / 10 / 2011 ; 17 / 3 / 2012 ; \\
6 / 7 / 2012 ; 16 / 10 / 2012 ; \\
10 / 2 / 2015\end{array}$ & 16 & 6.898 & 431,125 \\
\hline
\end{tabular}


Quadro 11

Estatutos Partidos Políticos. Alterações.

\begin{tabular}{|c|c|c|c|c|}
\hline Sigla & Datas & Alterações & Intervalos* & $\begin{array}{l}\text { Intervalos / } \\
\text { alterações }\end{array}$ \\
\hline PEN & $\begin{array}{c}19 / 6 / 2012 ; 6 / 4 / 2013 \\
15 / 01 / 2015\end{array}$ & 2 & 926 & 463 \\
\hline PP & $\begin{array}{c}\text { 13/9/1995; 20/3/1996; } \\
\text { 15/8/1996; 11/11/1997; } \\
\text { 9/12/1998; 11/11/1999; } \\
3 / 4 / 2001 ; 4 / 4 / 2003 ; \\
\text { 7/4/2005; } 2 / 4 / 2009 ; \\
\text { 11/4/2013 }\end{array}$ & 10 & 6.328 & 632,8 \\
\hline PR & $\begin{array}{l}26 / 10 / 2006 ; 19 / 4 / 2009 ; \\
28 / 3 / 2010 ; 21 / 10 / 2012\end{array}$ & 3 & 2.155 & 718,3333 \\
\hline DEM & $\begin{array}{c}7 / 5 / 1999 ; 8 / 5 / 2003 \\
16 / 6 / 2005 ; 28 / 3 / 2007 \\
12 / 12 / 2007 \\
\end{array}$ & 4 & 3.095 & 773,75 \\
\hline PTN & $10 / 6 / 2003 ; 20 / 8 / 2005$ & 1 & 790 & 790 \\
\hline РТВ & $\begin{array}{c}\text { 13/3/1999; 15/12/2002; } \\
\text { 13/12/2005; 6/10/2006; } \\
\text { 7/3/2009; 19/6/2010; } \\
\text { 18/7/2012 }\end{array}$ & 6 & 4.805 & 800,8333 \\
\hline PTC & $\begin{array}{c}\text { 2/6/1997; 11/11/2000; } \\
\text { 4/5/2003; 24/3/2007; } \\
29 / 4 / 2008 ; 26 / 11 / 2009 ; \\
27 / 7 / 2012 ; 11 / 3 / 2013\end{array}$ & 7 & 5.679 & 811,2857 \\
\hline PSDC & $\begin{array}{c}10 / 2 / 1996 ; 20 / 8 / 1997 \\
\text { 28/8/1997; } 14 / 10 / 2004 ; \\
16 / 6 / 2006 ; 18 / 9 / 2007 \\
30 / 11 / 2010\end{array}$ & 6 & 5.330 & 888,3333 \\
\hline PRB & $\begin{array}{c}15 / 12 / 2003 ; 25 / 10 / 2005 \\
6 / 2 / 2008 ; 16 / 8 / 2009 ; \\
24 / 2 / 2014\end{array}$ & 4 & 3.669 & 917,25 \\
\hline PPS & $\begin{array}{c}22 / 6 / 1998 ; 20 / 8 / 2002 ; \\
28 / 3 / 2004 ; 7 / 12 / 2006 ; \\
9 / 8 / 2009 ; 11 / 4 / 2011 ; \\
6 / 12 / 2013 \\
\end{array}$ & 6 & 5.564 & 927,3333 \\
\hline PSD & $27 / 9 / 2011 ; 6 / 5 / 2014$ & 1 & 939 & 939 \\
\hline PCdoB & $\begin{array}{c}30 / 6 / 1999 ; 6 / 8 / 2000 ; \\
12 / 12 / 2001 ; 20 / 10 / 2005 ; \\
29 / 8 / 2010\end{array}$ & 4 & 4.019 & 1004,75 \\
\hline
\end{tabular}


Quadro 11

Estatutos Partidos Políticos. Alterações.

\begin{tabular}{|c|c|c|c|c|}
\hline Sigla & Datas & Alterações & Intervalos* & $\begin{array}{c}\text { Intervalos / } \\
\text { alterações }\end{array}$ \\
\hline PSC & $\begin{array}{l}11 / 3 / 1998 ; 24 / 9 / 2003 ; \\
26 / 2 / 2007 ; 1 / 10 / 2007\end{array}$ & 3 & 3.440 & 1146,667 \\
\hline PSDB & $\begin{array}{c}15 / 5 / 1999 ; 21 / 11 / 2003 ; \\
23 / 11 / 2007 ; 28 / 5 / 2011 ; \\
18 / 5 / 2013\end{array}$ & 4 & 5.043 & 1260,75 \\
\hline PV & $\begin{array}{c}30 / 7 / 1990 ; 6 / 9 / 1992 ; \\
\text { 19/11/1995; 6/5/2000; } \\
29 / 10 / 2005 ; 3 / 4 / 2009 ; \\
26 / 11 / 2011 \\
\end{array}$ & 6 & 7.676 & 1279,333 \\
\hline PDT & 14/1/1996; 27/8/1999 & 1 & 1.303 & 1303 \\
\hline PRP & $\begin{array}{c}25 / 5 / 1997 ; 24 / 8 / 2003 ; \\
26 / 12 / 2005 ; 1 / 9 / 2007 ; \\
11 / 01 / 2012\end{array}$ & 4 & 5.266 & 1316,5 \\
\hline PSTU & $\begin{array}{c}\text { 13/2/1996; 26/4/1998; } \\
28 / 6 / 2008 ; 20 / 9 / 2009 ; \\
17 / 03 / 2013\end{array}$ & 4 & 6.154 & 1538,5 \\
\hline PSB & $\begin{array}{c}25 / 4 / 1996 ; 20 / 8 / 2005 \\
6 / 6 / 2008 ; 2 / 12 / 2011 \\
\end{array}$ & 3 & 5.617 & 1872,333 \\
\hline PSOL & $6 / 6 / 2004 ; 1 / 4 / 2010$ & 1 & 2.095 & 2095 \\
\hline PT & $\begin{array}{l}22 / 12 / 1995 ; 11 / 3 / 2001 ; \\
5 / 10 / 2007 ; 12 / 12 / 2013\end{array}$ & 3 & 6.470 & 2156,667 \\
\hline PMN & $\begin{array}{c}3 / 12 / 1995 ; 12 / 12 / 2004 \\
6 / 4 / 2008\end{array}$ & 2 & 4.443 & 2221,5 \\
\hline PSL & $\begin{array}{c}10 / 3 / 1996 ; 14 / 2 / 2004 ; \\
21 / 12 / 2011 \\
\end{array}$ & 2 & 5.681 & 2840,5 \\
\hline PRTB & $15 / 12 / 1995 ; 30 / 1 / 2004$ & 1 & 2.925 & 2925 \\
\hline PMDB & $\begin{array}{c}15 / 4 / 1996 ; 11 / 3 / 2007 ; \\
2 / 3 / 2013 \\
\end{array}$ & 2 & 6.077 & 3038,5 \\
\hline PCB & $21 / 1 / 1996 ; 23 / 3 / 2008$ & 1 & 4.382 & 4382 \\
\hline PTdoB & $6 / 4 / 1996 ; 27 / 6 / 2010$ & 1 & 5.121 & 5121 \\
\hline $\mathrm{PCO}$ & 9/12/1995 & 0 & 0 & 0 \\
\hline PPL & $4 / 10 / 2011$ & 0 & 0 & 0 \\
\hline PROS & $24 / 9 / 2013$ & 0 & 0 & 0 \\
\hline
\end{tabular}

Fonte: Elaborada pelos autores, a partir de dados disponíveis no site do TSE (http://www.tse.jus.br/ partidos/partidos-politicos/registrados-no-tse; a partir de onde acessa-se página individualizada para cada partido. Acessado em: 18/06/2015). * Em dias. 
Analisando-se os dados do Quadro 11, verifica-se que há uma alteração estatutária a cada 1.619 dias, ou $4,43 \operatorname{anos}^{25}$. O estatuto mais perene é o do Partido da Causa Operária, que não sofreu nenhuma alteração no período de 9/12/1995 a 30/6/2015, totalizando 7.041 dias sem alteração, ou 19,3 anos. O menor prazo de vigência foi do estatuto do Partido Humanista da Solidariedade (PHS) - 100 dias, no período de 17/3/2012 a 6/07/2012, ou 0,27 ano. O PHS apresentou também a maior quantidade de alterações - 16. É revelador que o partido que apresenta, pelo estatuto, a estrutura mais autoritária, seja também o que tenha promovido a maior quantidade de alterações estatutárias - se a norma não me serve mais, mude-se a norma.

Evidentemente, momentos específicos de alteração do contexto político podem levar muitos partidos a fazerem alterações simultaneamente. O presente artigo, contudo, não pretende buscar as causas das mudanças estatutárias. Estudos dessa natureza poderão desvendar se as alterações são mais relacionadas ao uso dos estatutos, que, como as leis, apresentam problemas de aplicação e necessidades de revisão ou se vinculadas a processos intencionais.

Para fins comparativos, na última coluna da tabela chega-se à quantidade de alterações por período ${ }^{26}$. Por esse critério, o partido com estatuto mais alterado é o Solidariedade (SD), com uma alteração a cada 320 dias, ou 0,87 ano. Catorze partidos tiveram alterações em prazos inferiores a três anos (1.095 dias). Calculando-se a média desta coluna, obtém-se o valor de uma mudança a cada 1.403 dias ou 3,8 anos. A estátua estatutária dos partidos é, na verdade, como essas estátuas humanas que se exibem nas ruas: eppur si muove.

\section{CONCLUSÕES}

Sucessivas pesquisas de opinião pública apontam para a falta de credibilidade do sistema político, atualmente fundamentado na concorrência aberta entre partidos políticos. Capturados pela lógica da esfera midiática, dependentes de lideranças personalizadas, induzidos a práticas heterodoxas para obtenção de fundos de campanha, forçados a posturas reativas diante de reiterados escândalos, os partidos políticos têm perdido seu papel de protagonistas e dinamizadores do sistema político (ou, no mínimo, têm mudado de papel, mantendo protagonismo eleitoral). 
O presente artigo, partindo de uma perspectiva normogenética, identificou como elementos facilitadores do processo de oligarquização inscreveram-se nas normas instituintes dos próprios partidos - seus estatutos. Uma vez incrustados nos estatutos, esses elementos tornam-se causas da oligarquização e a institucionalizam. Para usar termos do institucionalismo tradicional, convertidos em artigos estatutários, os elementos oligarquizantes geram path dependences. Evidente que as construções normativas são incapazes de moldar completamente a ação política, bem como não provocam, por si só, o fenômeno das oligarquias partidárias. Entretanto, a identificação desses elementos nos estatutos partidários vai um passo além das intuições empíricas dos autores clássicos mencionados (ie, Duverger, 1980, falava em tendência geral dos partidos no sentido da oligarquia).

Da pesquisa surgiram, presentes nos estatutos dos partidos políticos brasileiros, os seguintes marcadores oligárquicos:

- condições de filiação e para a manutenção da filiação, notadamente as restrições e o controle exercido sobre filiações de lideranças político-partidárias já reconhecidas;

- organização administrativa de cunho conexional, com amplas possibilidades intervencionistas dos órgãos superiores nos órgãos inferiores, tanto em termos hierárquicos quanto em termos geográficos;

- enfeixamento de amplos poderes (plenos nos interregnos dos congressos e convenções) em comissões executivas reduzidas, inclusive de convocação e presidência dos diretórios e convenções;

- manutenção de intrincada rede de membresias nativas nos órgãos deliberativos, diretivos e nas comissões executivas;

- existência e atuação de órgãos com competências amplas e ambíguas, como conselhos políticos, amplamente ocupados por lideranças partidárias já consolidadas e tradicionais;

- adoção de sistema eleitoral indireto para a ocupação dos cargos diretivos do partido, somado à prática de eleição mediante inscrição de chapas;

- possibilidade incondicional de reeleição dos dirigentes partidários;

- exigência de pré-requisitos aos candidatos a cargos diretivos no partido, inclusive de critérios ambíguos e de aplicação discricionária;

- alterações sucessivas nos estatutos, ao sabor e conveniência das lideranças partidárias existentes. 
Amaral (2013) cita uma corrente da literatura que aponta para a democratização interna dos partidos, verificando-se uma transferência de poder para o conjunto de filiados (Seyd e Whiteley, 2002; Kittilson e Scarrow, 2003; Freidenberg, 2005; Scarrow e Gezgor, 2010; Cross e Blais, 2012). Pelo menos do ponto de vista estatutário e analisado o caso brasileiro, isso não se confirma. Esse achado está também presente no trabalho de Ribeiro:

nas reformas estatutárias realizadas nos últimos 15 anos, veem-se indícios de que as lideranças nacionais de alguns dos maiores partidos têm agido no sentido de promover graus maiores de centralização e articulação interna de suas agremiações (Ribeiro, 2013:254).

Os estatutos partidários, como parte integrante do processo de institucionalização dos partidos, consolidam técnicas que permitem a manutenção do controle do partido por uma pequena elite dirigente.

(Recebido para publicação em 24 de fevereiro de 2016)

(Reapresentado em 21 de outubro de 2019)

(Aprovado para publicação em 20 de março de 2019)

\section{NOTAS}

1 As referências aos textos estatutários são feitas apenas com as siglas dos partidos e são sempre à última versão aprovada do Estatuto, disponível no site do Tribunal Superior Eleitoral. Portanto, todos os estatutos apreciados foram aprovados após a aprovação da Lei n⿳⺈ 9.096, que é o atual marco legal dos partidos políticos. Neste sentido, a pesquisa é a análise pontual de uma organização, sua situação atual, desconsiderada sua evolução.

2 Ainda segundo Duverger (1980), somente os partidos de massas conheciam um mecanismo formal de adesão. Ressalte-se, entretanto, que esse próprio autor divisava que a distinção entre partidos de quadros e partidos de massas viria a desaparecer, com todos os partidos adotando os procedimentos e as técnicas dos partidos de massas.

3 Recentemente, chegou à mídia um exemplo claro da utilização dessa "barreira à entrada". Diante de um processo de luta pela liderança do partido na Câmara dos Deputados, o então presidente do PMDB, Michel Temer, orientou a Executiva Nacional do partido a impugnar a filiação de deputados federais que pudessem favorecer $\mathrm{o}$ candidato que era contrário ao seu interesse (Folha de São Paulo, 11/12/2015).

4 Lei no 9.096/95, art. 22. “o cancelamento imediato da filiação partidária verifica-se nos casos de (...) V - filiação a outro partido". O parágrafo único desse artigo prevê também que, "havendo coexistência de filiações partidárias, prevalecerá a mais recente, devendo a Justiça Eleitoral determinar o cancelamento das demais".

5 Datas do deferimento do pedido de criação do partido no TSE. 
6 "Em casos de expulsão, a decisão deve ser ratificada pelo organismo imediatamente superior. Desligamento ou expulsão de membro do Comitê Central deve ser adotada por $2 / 3$ dos seus integrantes e ratificada pelo Congresso" (PCdoB, $\S 4^{\circ}$, art. 39).

7 Sintomático dessa situação é um desabafo do ex-presidente Lula: "o PT entrou na roda gigante da política. A gente só pensa em cargo, só pensa em emprego, só pensa em ser eleito, ninguém trabalha mais de graça" (Lula, Folha de S. Paulo, 23/06/2015, p. A6 "PT envelheceu, só quer cargos e precisa de revolução, diz Lula").

8 Kirchheimer (2012) discute como a seleção da liderança nos partidos se relaciona à perspectiva de cargos políticos.

9 Indiretamente, há outras formas de desfiliação. Exemplo: todos os estatutos trazem, como dever dos filiados, a contribuição financeira para o partido. E como motivo passível de processo disciplinar o não cumprimento dos deveres. Ou seja, indiretamente, o filiado pode vir a ser expulso pela inadimplência. Essa possibilidade não foi considerada. Foi assumida a cláusula de inadimplência apenas quando explicitamente mencionada como motivo de desfiliação e de forma direta.

10 Em sintonia com a lei, todas as situações de desfiliação preveem a possibilidade do exercício do amplo direito de defesa. Nos casos de desfiliação por não atendimento ao recadastramento, há previsões de comunicação ao filiado e a possibilidade de contestação por sua parte.

11 Isso fica claro, a título de exemplo, em PCdoB: "12. O partido constitui-se num sistema de organizações articuladas, disposto segundo o critério da divisão territorial administrativa do país, compreendendo instâncias e organismos superiores nacionais, instâncias intermediárias estaduais, municipais e locais, de caráter deliberativo". No Brasil os partidos se organizam com estruturas que espelham a estrutura federativa, como uma estrutura para cada cargo disponível.

12 Chamando o nível de "regional" ao invés de "estadual", pode-se manter um só órgão para mais de um estado, enquanto o partido não está complemente organizado. No caso do PV, existe a previsão da organização regional com competências próprias: “38. Caberá às coordenadorias regionais: I - traçar políticas específicas para a região (...)”.

13 Como exemplo, indica-se o caso do PT: cabe ao Congresso Nacional do Partido "126. analisar, discutir e deliberar sobre sua atuação política, sobre questões de âmbito nacional, atualização do programa, formas de organização ou funcionamento partidário".

14 Sympathy group, o número de pessoas com as quais o indivíduo pode ter simultaneamente uma relação empática forte. Ou seja, segundo a teoria, o grupo simpatético representa um limite em que decisões coletivas seriam, de fato, coletivas, podendo contar efetivamente com a participação de todos os envolvidos em uma decisão (cf. Dunbar, 1998).

15 Tradução livre dos autores para: "it is striking that groups of this size are common in situations where very close co-ordination of behavior is required: juries, the inner cabinets of many governments, the number of apostles, the size of most sport teams" (Dunbar, 1998:77).

16 Os movimentos religiosos pentecostais e neopentecostais são referência na utilização de células (pequenos grupos com reuniões frequentes, que devem se desdobrar quando alcançam determinado número) como mecanismo de aumento da membresia. 
17 O único partido a prever eleições diretas para todos os órgãos partidários é o PT. Trata-se de processo estritamente regulado e com algumas exigências aos eleitores, como o de ter participado em pelo menos uma atividade partidária em determinado prazo.

18 As exceções significam que não há indicação explícita, no Estatuto, da necessidade de chapa.

19 Excetua-se o PCB, que adota uma espécie de "lista aberta": PCB, 60, Parágrafo único: "em qualquer eleição partidária é possível a organização de listas nominais, tendo os votantes o direito de criticar e de substituir qualquer candidato que nelas figure e de votar em qualquer membro elegível".

20 PROS, 8, II: "não tenha sofrido qualquer sanção administrativa por insubordinação ou ofensa aos princípios da fidelidade partidária".

21 PDT, 26: “o PDT, na composição de todos os seus órgãos dirigentes e nominatas de candidatos a cargos eletivos, marcará a sua preferência pela de companheiros/as com razoável tempo de filiação e provindos das classes pobres e dos excluídos, com o necessário preparo pessoal ou representação social, entre trabalhadores, agricultores, assalariados em geral, sindicalistas, profissionais, pequenos empresários, aposentados, jovens, negros e mulheres"; PT, 22, XII: "na composição das direções, buscar-se-á o equilíbrio, levando-se em conta a participação dos militantes junto aos movimentos sociais, intelectuais, membros do Poder Executivo e parlamentares filiados e filiadas ao partido"; $\mathrm{PCdoB}, 18$ : "para eleger os/as integrantes dos organismos e órgãos dirigentes e delegados/as, é realizado um intenso e democrático trabalho de construção coletiva no âmbito das instâncias que os/as elegem, a partir de proposição inicial da direção, seguida de ampla consulta e debate, a fim de constituir proposta unitária que melhor represente as exigências da orientação geral do partido em cada jurisdição"; PHS, 52: "na escolha dos dirigentes do partido deve ser observado o quádruplo critério da ética, da competência, da disponibilidade e da adesão aos documentos de base do PHS"; PPL, 23: "o critério central para a escolha dos filiados para os cargos de direção é o compromisso demonstrado com o interesse coletivo da nação brasileira e da humanidade, aí compreendidos: I - a sensibilidade e o rigor na sua identificação; II - a energia e a determinação na sua defesa; III - a capacidade de sensibilizar e mobilizar o partido e o conjunto da sociedade para a sua conquista".

22 Os únicos partidos a apresentarem uma restrição à reeleição são o PT (apenas para o caso da Comissão Executiva - restringe a reeleição a três mandatos, de uma forma geral e a dois mandatos, quando se tratar do mesmo cargo) e o PPS (apenas uma reeleição para o mesmo cargo em Comissão Executiva).

23 Estatuto vem do latim statātum, que em cadeia vem de statutus, statuere (raiz comum à estátua e estatuto). Na sequência, vem de status, stare, que por sua vez derivam da raiz proto-indo-europeia stā.

24 “art. 6º §5ำ- Todo aquele que manifestar interesse em militar no PCB terá acesso prévio ao presente estatuto e às resoluções sobre política de organização, princípios ideológicos, tática e estratégia do Partido".

25 Para fins do cálculo dos intervalos totais, foi definida comparação com a data de 30/6/2015 para todos os partidos e incluído o intervalo entre a última alteração e esta data.

26 Calcula-se a soma dos intervalos entre as alterações para cada partido, e divide-se esse valor pela quantidade total de alterações estatutárias promovidas pelo partido. 


\section{REFERÊNCIAS BIBLIOGRÁFICAS}

AMARAL, Osvaldo. E. (2013), “O que sabemos sobre a organização dos partidos políticos: uma avaliação de 100 anos de literatura". Revista Debates, v. 7, n. 2, pp. 11-32. Disponível em: http://seer.ufrgs.br/debates/article/view/38429.

AMES, Barry. (2003), Os entraves da democracia no Brasil. Rio de Janeiro: FGV.

BARROS, Antonio Teixeira; RODRIGUES, Malena Rehbein; MARTINS, Lúcio Meireles. (2015), "Estratégias de educação política dos partidos brasileiros: as iniciativas digitais". Contextualizaciones Latinoamericanas, Ano 7, n. 13.

BRAGA, Maria do Socorro Sousa. (2012), "Democracia e organização nos partidos políticos: revisitando os microfundamentos de Michels". Revista de Sociologia e Política, v. 20, n. 44 , pp. 83-95.

CROSS, William; BLAIS, André. (2012), "Who selects the party leader?" Party Politics, v. 18, n. 2, pp. 127-150.

DALTON, Russell; WATTENBERG, Martin. (eds.). (2000), Parties without Partisans: political change in advanced industrial democracies. Oxford, Oxford University Press.

DUNBAR, Robin. (1998), Grooming, gossip and the evolution of language. Boston: Harvard University Press.

DUVERGER, Maurice. (1980), Os partidos políticos. Rio de Janeiro: Zahar/Brasília: UnB.

FOLHA DE S. PAULO. (2015), "Vice tenta barrar volta de líder na Câmara". A10, $11 / 12 / 2015$.

FREIDENBERG, Flavia. (2005), “Mucho ruído y pocas nueces. Organizaciones partidistas y democracia interna em América Latina". Polis: Investigación y Análisis Sociopolitico y Psicosocial, Iztapalapa, v. 1, n. 1, pp. 91-134.

HALL, Peter A.; TAYLOR, Rosemary C. R. (2003), "As três versões do neo-institucionalismo". Lua Nova, v. 58, pp. 193-223.

HAZAN, Reuven Y.; RAHAT, Gideon. (2010), Democracy within parties: candidate selection methods and their political consequences. Oxford: Oxford University Press.

JANDA, Kenneth; KING, Desmond. (1985), "Formalizing and testing Duverger's theories on political parties". Comparative Political Studies, v. 18, n. 2, pp. 139-169.

KATZ, Richard; MAIR, Peter. (1995), “Changing models of party organization and party democracy: the emergence of the cartel party". Party Politics, v. 1, n. 1, pp. 5-28.

KIRCHHEIMER, Otto. (2012), “A transformação dos sistemas partidários da Europa Ocidental". Revista Brasileira de Ciência Política, n. 7. pp. 349-385.

KITTILSON, Miki; SCARROW, Susan. (2003), "Political parties and the rhetoric and realities of democratization". In: B. Cain; R. Dalton; S. Scarrow (ed.), Democracy transformed? Expanding political opportunities in advanced industrial democracies. Oxford: Oxford University Press..

MAINWARING, Scott P. (2001), Sistemas partidários em novas democracias: o caso do Brasil. Rio de Janeiro: FGV. 
MANIN, Bernard. (2013), "A democracia do público reconsiderada". Novos Estudos CE$B R A P$, n. 97, pp. 115-127.

MEDDING, Peter Y. (1980), "A framework for the analysis of power in political parties". Political Studies, v. 18, n.1, pp. 1-17.

MICHELS, Robert. (1949), Political parties. A sociological study of the oligarchical tendencies of modern democracy. London: Edição Kindle.

MOSCA, Gaetano. (2009), Elementi di Scienza Politica. Milão: Bibliolife.

PANEBIANCO, Angelo. (2005), Modelos de partido: organização e poder nos partidos políticos. São Paulo: Martins Fontes.

RAHAT, Gideon; HAZAN, Reuven Y.; KATZ, Richard S. (2008), "Democracy and political parties: on the uneasy relationships between participation, competition and representation". Party Politics, v. 14, n. 6, pp. 663-683.

RIBEIRO, Pedro Floriano. (2013), “Organização e poder nos partidos brasileiros: uma análise dos estatutos". Revista Brasileira de Ciência Política, n. 10, pp. 225-265.

SARTORI, Giovanni. (1982), Partidos e sistemas partidários. Rio de Janeiro: Zahar/Brasília: UnB.

SCARROW, Susan; GEZGOR, Burcu. (2010), "Declining memberships, changing members? European political parties in a new era". Party Politics, v. 16, n. 6, p. 823-843.

SEYD, Patrick; WHITELEY, Paul. (2002), High-intensity participation: the dynamics of party activism in Britain. Ann Harbor, UMP.

TESSEROLI FILHO, Nourmiro Bittencourt. (2015), O cidadão na Constituição Federal de 1988. Disponível em: www.ordemmais.com.br/para-estudar-materia.php?cod=54; Acessado em: 22/6/2015.

VAN BIEZEN, Ingrid; MAIR, Peter; POGUNTKE, Thomas. (2012), “Going, going, ... gone? The decline of party membership in contemporary Europe". European Journal of Political Research, v. 51, pp. 24-56.

WEBER, Max. (1999), Economia e sociedade. Brasília: UnB. 


\section{RESUMO}

A Oligarquia Desvendada: Organização e Estrutura dos Partidos Politicos Brasileiros

O presente artigo foca na organização e estrutura interna dos partidos políticos brasileiros, a partir de uma abordagem institucionalista tradicional, uma vez que se busca compreender como um conjunto específico de regras (estatutos partidários) pode afetar a comunidade de atores (partidos, lideranças partidárias, filiados) e as relações entre esses grupos. Pretende-se com o estudo, a partir de uma perspectiva normogenética, identificar como se organizam e estruturam internamente os partidos políticos brasileiros. A partir dessa identificação, busca-se verificar os elementos organizativos ou estruturais que configurem tipos de comportamento partidários, como características oligárquicas nos partidos políticos brasileiros, em confronto com o anunciado por referências clássicas na literatura sobre partidos políticos. É uma pesquisa documental, de cunho exploratório e comparativo. Em alguns momentos, são construídos índices operacionais de caráter quantitativo. Entre os principais achados, está a identificação de como elementos facilitadores do processo de oligarquização inscreveram-se nas normas instituintes dos próprios partidos e, uma vez incrustados nos estatutos, esses elementos tornam-se causas da oligarquização e a institucionalizam. São apontados, também nas conclusões, vários elementos comuns nas normas partidárias que apontam para o processo de concentração de poder nos partidos, chamados de marcadores oligárquicos.

Palavras-chave: ciência política; partidos políticos; estatutos partidários; dirigentes partidários

\section{ABSTRACT \\ The Unveiled Oligarchy: Organization and Structure of Brazilian Political Parties}

This article focuses on the organization and internal structure of Brazilian political parties, based on a traditional institutionalist approach, seeking to understand how a specific set of rules (party statutes) can affect the community of actors (parties, party leaders, those affiliated) and the relationships between these groups. The intention of this study, from a normogenetic perspective, is first to identify how Brazilian political parties are organized and internally structured. After that, we sought to verify the organizational or structural elements that configure different types of party behavior, such as certain oligarchic characteristics in the Brazilian political parties, in contrast to what the classic references in the literature on political parties affirm. It is a documentary research, exploratory and comparative in nature. We constructed quantitative operational indexes when necessary. Among the main findings is the identification of how facilitators of 
the process of oligarchy were inscribed in the norms instituted by the parties themselves and, once embedded in the statutes, became propellers of oligarchy and institutionalized it. Also pointed out, in the conclusions, are several common elements in party norms that underline the process of power concentration in the parties, called oligarchic markers.

Keywords: political science; political parties; party statutes; party leaders

\section{RÉSUMÉ}

L'Oligarchie Dévoilee: Organisation et Structure des Partis Politiques Brésiliens

Cet article regarde l'organisation et la structure interne des partis politiques brésiliens, sur la base d'une approche institutionnaliste traditionnelle, car il cherche à comprendre comment un ensemble spécifique de règles (statuts de parti) peut affecter la communauté d'acteurs (partis, chefs de parti, affiliés) et les relations entre ces groupes. On est prévu d'étudier, d'un point de vue normogénétique, comment s'organisent et se structurent les partis politiques brésiliens. À partir de cette identification, on cherche à vérifier les éléments organisationnels ou structurels qui configurent les types de comportement de parti, tel que des caractéristiques oligarchiques dans les partis politiques brésiliens, par rapport à celui annoncé par les références classiques dans la littérature sur les partis politiques. C'est une recherche documentaire, exploratoire et comparative. À certains moments, des index opérationnels à caractère quantitatif sont construits. Parmi les principales conclusions, on trouve la manière dont les facilitateurs du processus d'oligarchisation s'ont été inscrits dans les normes instituées par les partis ils-mêmes et, une fois incorporés dans les statuts, ces éléments deviennent les causes de l'oligarchisation et l'institutionnalisent. Les conclusions soulignent également plusieurs éléments communs des normes des partis qui indiquent le processus de concentration du pouvoir dans les partis, appelés marqueurs oligarchiques.

Mots-clés: science politique; partis politiques; statuts du parti; chefs de parti 


\section{RESUMEN}

La Oligarquía Desvendada: Organización y Estructura de los Partidos Políticos Brasileros

El presente artículo se centra en la organización y estructura interna de los partidos políticos brasileros, a partir de un abordaje institucionalista tradicional, ya que se busca comprender de qué forma un conjunto específico de reglas (estatutos partidarios) puede afectar a la comunidad de actores (partidos, liderazgos partidarios, afiliados) y las relaciones entre esos grupos. Se pretende con el estudio, a partir de una perspectiva normogenética, identificar cómo se organizan y estructuran internamente los partidos políticos brasileros. A partir de esa identificación, se pretenden verificar los elementos organizativos o estructurales que configuran tipos de comportamiento partidarios, como las características oligárquicas en los partidos políticos brasileros, frente a lo anunciado por referencias clásicas en la literatura sobre partidos políticos. Esta, es una investigación documental, de carácter exploratorio y comparativo. En algunos momentos, se construyen índices operacionales de carácter cuantitativo. Entre los principales hallazgos, se encuentra la identificación de cómo los elementos facilitadores del proceso de oligarquización se inscribieron en las normas instituyentes de los propios partidos y, una vez incrustados en los estatutos, esos elementos se convierten en causas de la oligarquización, institucionalizándola. También en las conclusiones, son presentados varios elementos comunes a las normas partidarias que apuntan al proceso de concentración de poder en los partidos, denominados como marcadores oligárquicos.

Palabras clave: ciencia política; partidos políticos; estatutos partidarios; dirigentes partidarios 